\title{
Bibliography on birds of prey and owls in Slovakia. Part 5. General references and supplements to previous parts
}

\author{
Bibliografia dravcov a sov Slovenska. Čast 5. Všeobecná literatúra a doplnky \\ k predchádzajúcim častiam
}

\author{
Marcel UHRIN, Štefan DANKO \& Hana LATKOVÁ
}

\begin{abstract}
The aim of the bibliography is to provide a list of publications on the raptors and owls of Slovakia and of Slovak authors including articles dealing with various organisational issues. The previous parts, which focused on genera from the orders Accipitrifromes, Falconiformes and Strigiformes, are now followed by a fifth part focusing on the raptor and owl species mentioned in various wider associations in the individualarticles. The species, objective and author indexes and the list of periodicals enable better overview.
\end{abstract}

\begin{abstract}
Abstrakt: Ciel'om bibliografie je poskytnút' zoznam publikácií o dravcoch a sovách Slovenska ako aj prác od slovenských autorov vrátane rôznych organizačných správ. Na prvé časti zamerané na rody radov Accipitriformes, Falconiformes a Strigiformes nadväzuje piata čast’ zameraná na dravce a sovy spomínané v jednotlivých publikáciách v rôznych širších súvislostiach. Zoznam citácií sprehl'adňujú druhový, vecný a autorský register a zoznam periodík.
\end{abstract}

Key words: raptors, owls, references

Marcel Uhrin, Department of Zoology, Institute of Biology and Ecology, Faculty of Science, P. J. Šafárik University, Moyzesova 11, SK-040 01 Košice, Slovakia \& Department of Forest Protection and Wildlife Management, Faculty of Forestry and Wood Sciences, Czech University of Life Sciences, Kamýcká 1176, CZ-16521 Praha 6, Czech Republic. E-mail: marcel.uhrin@gmail.com. Štefan Danko, Hana Latková, Raptor Protection of Slovakia, Kuklovská 5, SK-841 04 Bratislava, Slovakia. E-mail: danko@gecom.sk, latkova@dravce.sk.

\section{Introduction}

The presented bibliography is a follow-up to the previous parts (Uhrin et al. 2008, 2009, 2010, 2011), which focused on different aspects of the biology of genera from the orders Accipitriformes, Falconiformes and Strigiformes. The historical backround as well as the methodology of its compilation, were described in the first part.

In this fifth part of the bibliography we present the papers on all raptor and owl species living in Slovakia in addition to all papers by Slovak authors, not just those focused on the particular species. The list is also amend by papers having organisational content (e.g. organisation information, personalia, etc.). The formal side of the reference list is compiled in a similar way as the previous parts. We focused on publications from scientific periodicals and scientific articles; references to papers from newspapers and popular magazines were not reviewed systematically and information from these sources was found more or less by accident. Only papers available up to the end of 2012 are included in the bibliographic list. Thus, supplemental references on a particular raptor and/or owl species then emerged prior to the above-mentioned date and not included in the previous parts are also given here.

The citations in the bibliography are arranged alphabetically by author and year of the edition, and the numeration continues from the previous parts. The title of an article is given in the language in which it was originally published, and the English translation is displayed in square brackets after the original name of the article, except for articles written in one of the so-called "world" languages. Information on the language of the abstract or summary and acronyms describing the character of the articles [scientific/research articles - SA, conference abstracts - CA, popular or magazine/newspaper articles PA, qualification papers (e.g. student works, thesis etc.) - QP, reports and/or other papers - RO] have been added to the citations. The species register, the objective index and the author register are included at the end of the bibliography. Other acronyms used: s. a. [sine anno] without year of edition; s. p. [sine paginatione] - unpaginated; ref. no. - reference number, referring to number of the reference in all parts of the bibliography; DOI Digital Objective Identification number. 


\section{Short reference analysis}

The whole bibliography (parts I.-V.) covers a period of 152 years (1861-2012), with the 1600 references gathered written by 508 different authors (anonymous authors were omitted from this statistic). The publications target several aspects of the natural history of raptors and owls in addition to the organisational activities connected with their research and protection.

\section{$\mathrm{H}$ i s t o r i c a l s k e t c h}

The beginning of raptor research in the territory of modern Slovakia dates from the period of the Austrian Empire (1804-1867) and the Austro-Hungarian Monarchy (1867-1918), with the first paper on Falco naumanni published in 1861 by L. H. Jeitteles [ref. no. 1565], followed in 23 years later in 1884 by two other papers, one on Aquila chrysaetos written by A. Kocyan [ref. no. 167] and the second a general article on the raptors of the respective region written by J. Madarász [ref. no. 1345]. A total of only twelve references on raptors and owls have been gathered from the monarchy period; these were written by various Slovak, Hungarian and Ukrainian authors (F. Fuchs, G. Geyer, S. Hrabár, A. Lendl, V. Mauks). The level of the research generally did not change after the establishment of an independent Czechoslovakia in 1918, nor until the end of the World War II. During this latter mentioned period only 26 more papers on both diurnal and nocturnal raptors appeared. These were written mainly by Czech (e.g. J. Baum, W. Černý, J. Jirsík, J. Musílek) and Hungarian (e.g. E. Bethlenfalvy, V. Greschik, I. Györffy, A. Lokcsánszky, J.

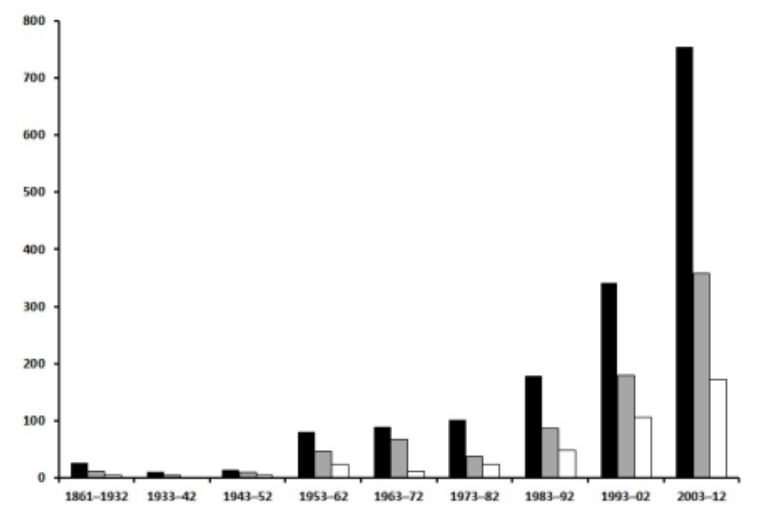

Fig. 1. Development of publication activity on raptors in Slovakia 1861-2012. Black columns - all references, grey columns - diurnal raptors, white columns - owls.

Obr. 1. Vývoj publikačnej aktivity o dravoch na Slovensku v období 1861-2012. Čierne stípce - všetky práce, sivé stípce denné dravce, biele stlpce - sovy.
Schenk) authors but also by the first Slovak authors (e.g. O. Ferianc, J. Martinka, F. Matoušek, J. Brtek). For more details on the early history of ornithology in the territory of Slovakia, see more specialised sources (for example Matoušek 1961; Mošanský 1966, 1984). Rapid development of raptor research began only after World War II, innitially conducted mainly by several Czech authors with the continuously increasing activity of Slovak authors. The development of publication activity is given in Fig. 1, wich clearly shows a rapid increase in reference numbers during the last two decades evaluated (1993-2012). There are no significant differences between publication activity when comparing papers on raptors separately from papers on owls (Fig. 1).

P a p e r c h a r a t e r a n d o p i c s Among all of the compiled references, "scientific" articles predominanate (49.6\%; Fig. 2). These types of papers should be understood under a very broad definition in terms of their scientific character, in that they also include all types of original works, including faunistic papers, ringing reports, etc., and some of them do not set any scientific hypotheses. This is also reflected in fact that only $33(2.1 \%)$ papers from all of the registered reference items in the compiled bibliography were published in the relevant journals (Web of Knowledge Databasis; searched on December 20, 2012). Thus, the state of research on owls and raptors in Slovakia is on a very low scientific level and reflects the state of ornithological research as whole in Slovakia (see e.g. Václav 2008). This is corroborated by the number of popular

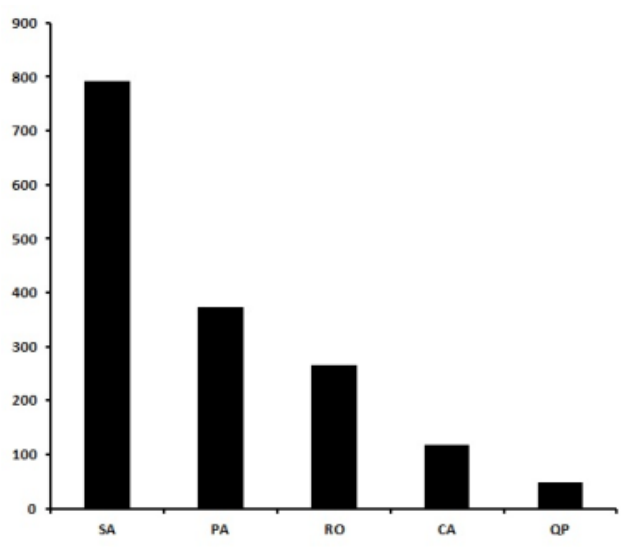

Fig. 2. Proportion of various types of papers gathered in the bibliography [\%]. For explanation of categories see the "Introduction" chapter.

Obr. 2. Zastúpenie jednotlivých typov publikácií v bibliografii [\%]. Význam kategórií je vysvetlený v kapitole "Introduction". 
articles, which represent almost one-quarter of all the bibliographic items (23.4\%; Fig. 2). Scientific and popular articles are followed by several kinds of reports $(16.6 \%)$ and by a few conference abstracts $(7.4 \%)$ and qualification papers (3.0\%). Among qualification papers graduate theses dominated, only three $\mathrm{PhD}$ theses were successfully defended, all on owls (Otus scops, ref. no. 1111; Athene noctua, ref. no. 933; Strix aluco, ref. no. 1044). One reason for the relatively low scientific value of "raptor" research in Slovakia is the fact, that no professional organisation specialised in these predators exists in the country and most research and protection of raptors and owls is conducted by members of nongovermental organisations voluntarily or within their running projects. This is also reflected in the proportion of authors, sharing the most items in the bibliography (Fig. 3). Most of them are not professional zoologists. These 18 authors (with twenty or more references in the bibliography) represent only $3.5 \%$ of all authors registered in the dataset yet they participated in $51.0 \%$ of all the references gathered. Most of the papers (48.1\%) deal with the most species-abundant order, Accipitriformes (Fig. 4) followed by papers on Strigiformes $(29.4 \%)$ and on Falconiformes (22.5\%). Comparing papers on the species level (Fig. 5), it is clear that the most references are on endangered and rare species (cf. Krištín et al. 2001) and on those species, which are targeted by well-financed projects, for example from the European Commission within the LIFE Programme (e.g. Aquila heliaca, Falco cherrug, Aquila pomarina).

\section{References}

Krištín A, Kocian L \& Rác P 2001: Červený (ekosozologický) zoznam vtákov (Aves) Slovenska [Red Data List of birds (Aves) of Slovakia], 150-153. In: Baláž D, Marhold K \& Urban P (eds), Červený zoznam rastlín a živočíchov Slovenska [Red Data List of plants and animals of Slovakia]. Ochrana prírody 20, Supplement, 160. [In Slovak]

Matoušek B 1961: Faunistický prehl'ad slovenského vtáctva. Čast' I [Faunistic review of birds of Slovakia. Part I]. Prírodovedný sborník Slovenského múzea 7: 3-109. [In Slovak]

Mošanský A 1966: Dejiny a súčasný stav ornitologického výskumu a zberatel'skej činnosti na východnom Slovensku [Geschichte und heutiger Stand der ornitologischen Forschung und der Sammlertätigkeit in der Ostslowakei]. Sborník Východoslovenského múzea, zoológia - botanika 6B: 7-25. [In Slovak with German summary]
Mošanský A 1984: Pohl'ady do histórie ornitologickej činnosti na východnom Slovensku [Rückblicke der Geschichte der ornitologischen Tätigkeit in der Ostslowakei]. Milvus 1: 3-10. [In Slovak with German summary]

Uhrin M, Danko Š \& Latková H 2008: Bibliography on birds of prey and owls in Slovakia. Part 1. Order Accipitriformes, genera Aquila, Hieraaetus \& $\mathrm{Ha}$ liaeetus. Slovak Raptor Journal 2: 119-142. DOI: 10.2478/v10262-012-0026-2.

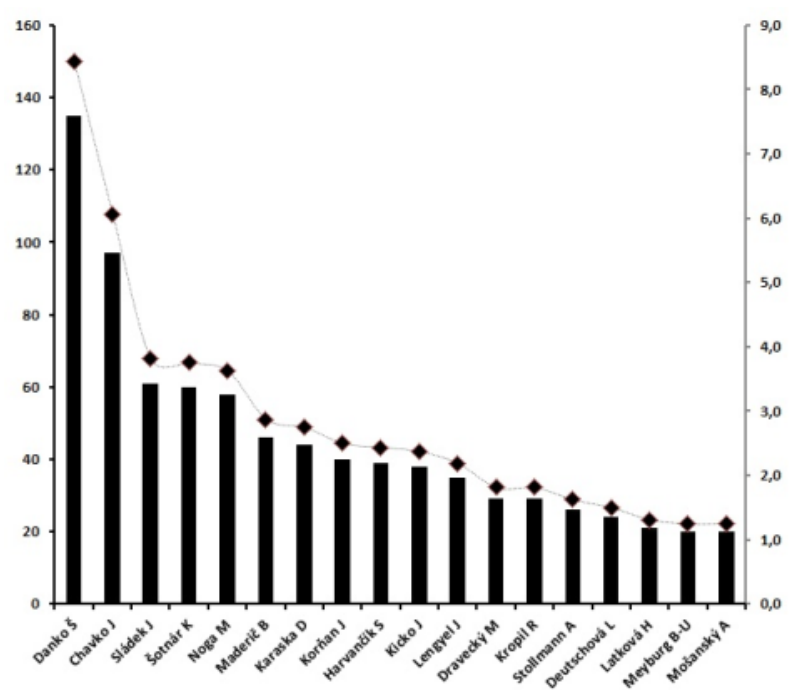

Fig. 3. Proportion of authors for all papers gathered in the bibliography, exact numbers of references [columns, left $y$-axis] and percentages [diamonds, right $y$-axis]. Only authors with twenty or more references of all types are displayed.

Obr. 3. Zastúpenie autorov na citáciách v bibliografii, počty publikácií [stĺpce, l'avá os y] a percentá [kosoštvorce, pravá os y]. Zobrazení sú len autori dvadsiatich a viac publikácií všetkých typov.

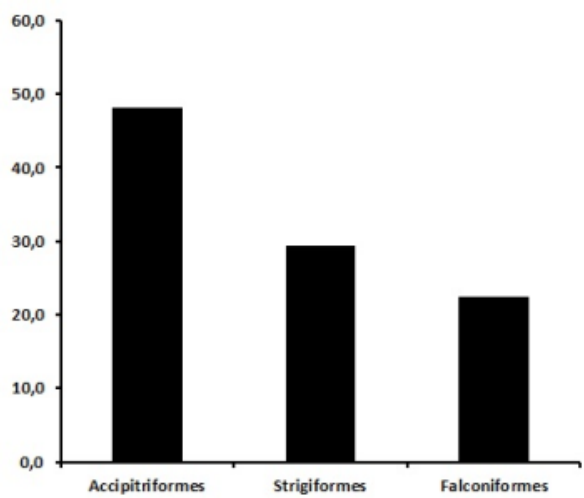

Fig. 4. Proportion of references for particular orders $[\%$; $\mathrm{n}=1513]$.

Obr. 4. Zastúpenie citácií podla radov [\%; $n=1513]$. 
Uhrin M, Danko Š \& Latková H 2009: Bibliography on birds of prey and owls in Slovakia. Part 2. Order Accipitriformes, genera Pernis, Milvus, Neophron, Gyps, Aegypius, Circaetus, Circus, Accipiter, Buteo \& Pandion. Slovak Raptor Journal 3: 73-88. DOI: 10.2478/v10262-012-0036-0.

Uhrin M, Danko Š \& Latková H 2010: Bibliography on birds of prey and owls in Slovakia. Part 3. Order Falconiformes, genus Falco. Slovak Raptor Journal 4: 115-131. DOI: 10.2478/v10262-012-0055-x.

Uhrin M, Danko Š \& Latková H 2011: Bibliography on birds of prey and owls in Slovakia. Part 4. Order Strigiformes, genera Tyto, Otus, Bubo, Strix, Surnia,
Glaucidium, Athene, Aegolius \& Asio. Slovak Raptor Journal 5: 137-163. DOI: 10.2478/v10262-012-0061-z.

Václav R 2008: Špecifiká a výzvy súčasnej slovenskej ornitológie [Characteristics and challenges of the current Slovak ornithology]. Tichodroma 20: 183-189. [In Slovak with English abstract]

\section{Bibliographical review of articles}

The bibliography contains in total 403 citations of different articles. In the register are in total $124(30.8 \%)$ scientific and research articles, 57 (14.1\%) popular articles, $8(2.0 \%)$ qualification papers, $22(5.5 \%)$ conference abstracts and $192(47.6 \%)$ reports or other papers.
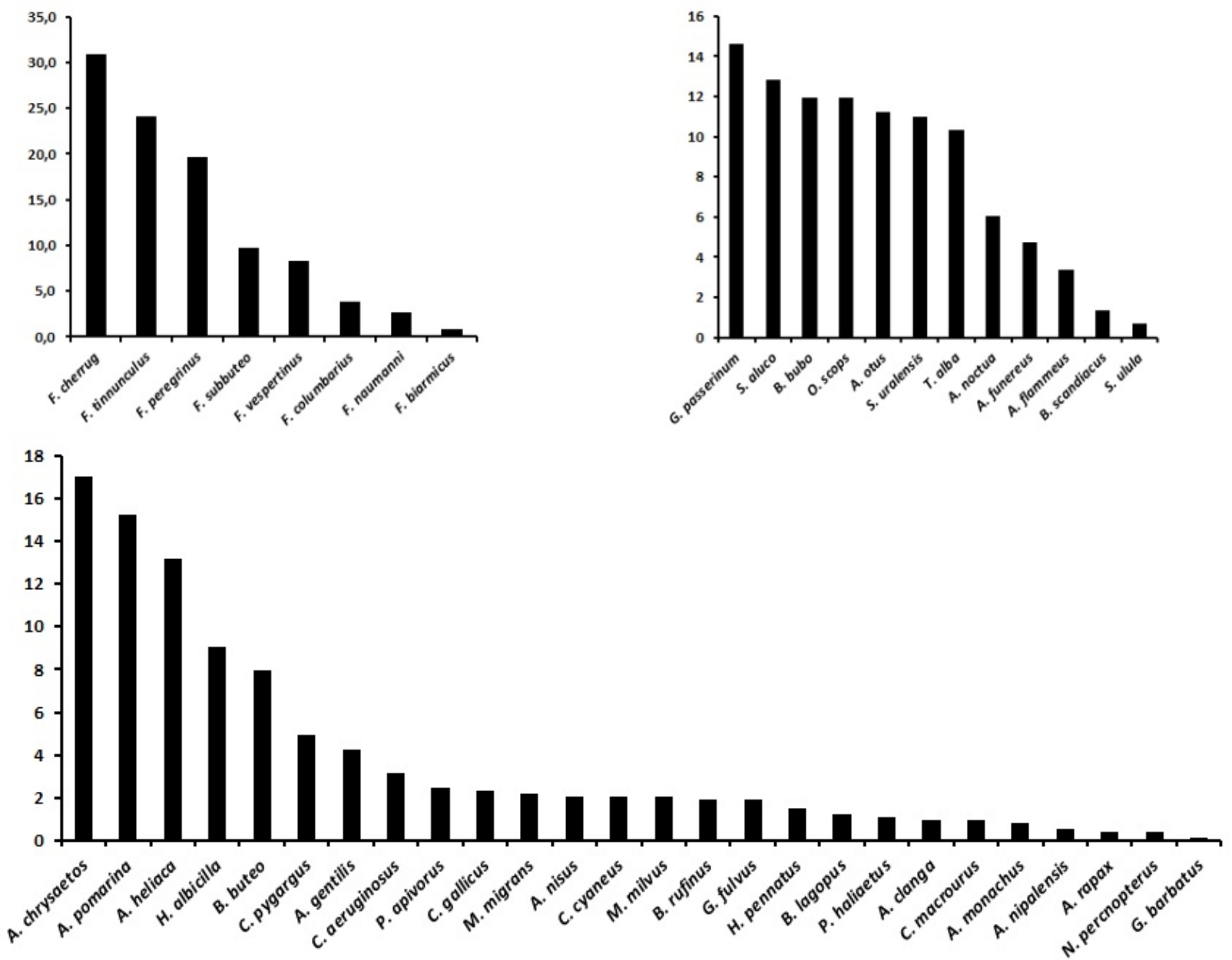

Fig. 5. Proportion of particular species occurring in Slovakia in the bibliography references [\%]. Falconiformes, above left [ $n=340]$; Strigiformes, above right [ $\mathrm{n}=445]$; and Accipitriformes, bottom [ $\mathrm{n}=728]$

Obr. 5. Zastúpenie jednotlivých druhov, žijúcich na Slovensku, v citáciách bibliografie [\%]. Falconiformes, hore vlavo [n=340], Strigiformes, hore vpravo [n=445] a Accipitriformes, dole [n=728]. 
G e n e r a 1 refere n c e s

[1198] Adamec M 1999: Birds of Prey Saving Club. Buteo Supplement: 40-41. RO

[1199] Adamec M 1999: S.C.R.O. - Society for the Conservation and Research of Owls, Canada. Buteo Supplement: 39. RO

[1200] Adamec M 1999: World Owl Trust (W.O.T.), United Kingdom. Buteo Supplement: 40. RO

[1201] Adamec M 2001: Výsledky rehabilitácie dravcov a sov $\mathrm{v}$ regióne Banskej Bystrice [Results of raptors and owls rehabilitation in Banská Bystrica region], 272-275. In: Turisová I (ed), Ekologická diverzita modelového územia banskobystrického regiónu. Zborník referátov z celoslovenskej vedeckej konferencie [Ecological diversity of Banská Bystrica Region as model territory. Proceedings from scientific conference]. Śtátna ochrana prírody - Centrum ochrany prírody a krajiny, Katedra ekológie a environmentálnej výchovy Fakulty prírodných vied UMB \& Stredoslovenské múzeum, Banská Bystrica, 294. [In Slovak] SA

[1202] Adamec M 2002: Výsledky rehabilitácie sov a dravcov na území Stredoslovenského kraja [Results of raptors and owls rehabilitation in central Slovakia], 147. In: Bryja J \& Zukal J (eds), Zoologické dny Brno 2002. Zborník abstraktů z konference 14.-15. února 2002 [Zoological days Brno 2002. Abstract proceedings from conference, February 14-15, 2002]. Ústav biologie obratlovců, Brno, 191. [In Slovak] CA

[1203] Adamec M 2003: Rehabilitácia chránených druhov vtáctva ako obetí vtáčej kriminality [Rehabilitation of protected birds caused by bird crime], 10-11. In: Šutiaková T \& Brinzík M (eds), Zborník abstraktov z odborného seminára "Spoločne proti vtáčej kriminalite" [Abstract proceedings from seminar "Against bird crime together"]. SOVS, Bratislava, 21. [In Slovak] CA

[1204] Adamec M 2004: Birds and power lines - status in the Slovak Republic, 417-421. In: Chancellor RD \& Meyburg B-U (eds), Raptors worldwide. World working group on birds of prey and owls, Hancock House, Blaine, Washington, USA, 890. SA

[1205] Anonymus 1977: Zoznam účastníkov - Liste der Teilnehmer - List of participants, 6-7. In: Randík A (ed), Falconiana I. Súbor referátov zo seminára "Súčasný stav rozšrirenia a ochrany dravých vtákov v Československu", Nitra, 24.-25. septembra 1976 [Falconiana I. Proceedings from seminar "Current state of distribution and protection of raptors in Czechoslovakia", Nitra, September 24-25, 1976]. Ústav experimentálnej fytopatológie a entomológie SAV, Sekcia ochrany fauny Slovenskej zoologickej spoločnosti SAV \& Sekcia ochrany vtáctva Československej ornitologickej spoločnosti, Bratislava, 107. RO

[1206] Anonymus 2005: Ochrana dravcov na Slovensku - Raptor protection of Slovakia. Dravce a sovy 1(1): 2. [In Slovak] RO

[1207] Anonymus 2005: Z činnosti RPS v roku 2004 ... alebo čo sa nám všetko podarilo urobit? [From acitivity of RPS in $2004 \ldots$ or what we succed to do]. Dravce a sovy 1(1): 4-5. [In Slovak] RO

[1208] Anonymus 2006: Národný park Nízke Tatry a fauna [Nízke Tatry Mts. National Park and fauna], 31-40. In: Jasík M, Mezei A, Kaliský M, Kuna F \& Hančin M (eds), Správa Národného parku Nízke Tatry. Ročenka 2006 [Administration of Nízke Tatry National Park. Yearbook 2006]. Štátna ochrana prírody Slovenskej republiky, Správa Národného parku Nízke Tatry, Liptovský Hrádok, 62. [In Slovak] RO

[1209] Anonymus 2007: Vol'by 2006 [Election 2006]. Dravce a sovy 3(1): 4. [In Slovak] RO

[1210] Anonymus 2012: Nová informačná tabul'a ochrana sokola rároha [New information board on saker falcon]. Dravce a sovy 8(2): 25. [In Slovak] RO

[1211] Anonymus (Mk \& Pu) [Uhrin M \& Kan̆uch P] 2007: Recenzia: Slovak Raptor Journal 1 (2007). C̆asopis pre vedu, výskum a ochranu dravcov a sov na Slovensku [Review: Slovak Raptor Journal 1 (2007). Journal for science, research and conservation on birds of prey and owls in Slovakia]. Tichodroma 19: 162. [In Slovak] RO

[1212] Anonymus (Redakce) 1981: Vážení přátelé, ... [Dear friends, ...]. Skupina pro výzkum dravých ptáků a sov, Zprávy 1: 1-2. [In Czech] RO

[1213] Anonymus (Redakce) 1986: Ornitologická pozorování [Ornitological observations]. Zprávy MOS 44: 127-136. [In Czech] RO

[1214] Anonymus (Redakce) 1988: Vážení přátelé, ... [Dear friends, ...]. Buteo 1[1986]: 1. [In Czech] RO

[1215] Anonymus (Redakce) 1992: Ornitologická pozorování [Ornitological observations]. Moravský ornitolog 1: 24-31. [In Czech] RO 
[1216] Anonymus (Účastníci Seminára) 1977: Stanovisko a odporúčania $\mathrm{k}$ súčasnému stavu a ochrane dravých vtákov v Československu. Standpoint and recommendations to the present state and birds of prey protection in Czechoslovakia, 89-92. In: Randík A (ed), Falconiana I. Súbor referátov zo seminára "Súčasný stav rozšírenia a ochrany dravých vtákov v Československu", Nitra, 24.-25. septembra 1976 [Falconiana I. Proceedings from seminar "Current state of distribution and protection of raptors in Czechoslovakia", Nitra, September 24-25, 1976]. Ústav experimentálnej fytopatológie a entomológie SAV, Sekcia ochrany fauny Slovenskej zoologickej spoločnosti SAV \& Sekcia ochrany vtáctva Československej ornitologickej spoločnosti, Bratislava, 107. RO

[1217] Babó T 1977: Biologická ochrana polnohospodárskych plodín [Biological protection of agriculutral crops], 72-74. In: Randík A (ed), Falconiana I. Súbor referátov zo seminára "Súčasný stav rozšírenia a ochrany dravých vtákov v Československu", Nitra, 24.-25. septembra 1976 [Falconiana I. Proceedings from seminar "Current state of distribution and protection of raptors in Czechoslovakia ", Nitra, September 24-25, 1976]. Ústav experimentálnej fytopatológie a entomológie SAV, Sekcia ochrany fauny Slovenskej zoologickej spoločnosti SAV \& Sekcia ochrany vtáctva Československej ornitologickej spoločnosti, Bratislava, 107. [In Slovak with English summary] SA

[1218] Babó T 1977: Vspomienka na dr. Jozefa NagyChrenóczyho (25. VII. 1818 - 11. II. 1892) [Memory on dr. Jozefa Nagy-Chrenóczyho (25. VII. 1818 - 11. II. 1892)], 105-107. In: Randík A (ed), Falconiana I. Súbor referátov zo seminára "Súčasný stav rozšírenia a ochrany dravých vtákov v Československu", Nitra, 24.-25. septembra 1976 [Falconiana I. Proceedings from seminar "Current state of distribution and protection of raptors in Czechoslovakia", Nitra, September 24-25, 1976]. Ústav experimentálnej fytopatológie a entomológie SAV, Sekcia ochrany fauny Slovenskej zoologickej spoločnosti SAV \& Sekcia ochrany vtáctva Československej ornitologickej spoločnosti, Bratislava, 107. [In Slovak with English summary] RO
[1219] Babó T 1978: Biologická ochrana pol’nohospodárskych plodín [Biological protection of agriculutral crops], 26-27. In: Sedláček K \& Pecina P (eds), Sborník referátů a příspěvků z celostátní pracovní porady "Dravci 1977", Davle u Prahy, 6.-9. 9. 1977. 1. díl [Proceedings from working meeting "Raptors 1977", Davle near Praha, September 6-9, 1977. Part 1]. Středisko státní památkové péče a ochrany prírody Středočeského kraje, Státní ústav památkové péče a ochrany přírody \& Ústřední výbor Českého mysliveckého svazu, Brno, 106. [In Slovak] SA

[1220] Bačíková S \& Fend'a P 2010: Roztoče (Acari, Mesostigmata) v hniezdach dravých vtákov (Aves: Falconiformes) na Slovensku [Mites (Acari, Mesostigmata) in nests of raptors (Aves: Falconiformes) in Slovakia], 22. In: Bryja J \& Zasadil P (eds), Zoologické dny Praha 2010. Sborník abstrakti̊ z konference 11.-12. února 2010 [Zoological days Praha 2010. Abstract proceedings from conference, February 11-12, 2010]. Ústav biologie obratlovců AV ČR, Brno, 277. [In Slovak] CA

[1221] Barčák C \& Chavko J 1994: Ochrana dravých vtákov so zretel'om na kriticky ohrozené druhy v Chránenej krajinnej oblasti Malé Karpaty [Birds of prey protection with emphasis on criticall endangered species in Malé Karpaty Mts Protected Landscape Area], 261-265. In: Baláž D (ed), Ochrana biodiverzity na Slovensku, Zborník referátov zo seminára v Záhorskej Bystrici 1993 [Biodiverzity protection in Slovakia. Proceedings from seminar in Záhorská Bystrica 1993]. Slovenská riečna siet' \& Katedra ekosozológie a fyziotaktiky, Prírodovedecká fakulta, Univerzita Komenského, Bratislava, 388. [In Slovak] SA

[1222] Beneš B, Hanák F \& Hudeček J 2005: Ptáci České a Slovenské republiky ve Slezském zemském muzeu Opava [Birds from Czech and Slovak Republics in Silesian Museum in Opava]. Zprávy MOS 63: 143-206. [In Czech] SA

[1223] Benko Š 2001: Sokoliarstvo - názory a fakty III [Falconry - opinions and facts III]. Vtáčie správy 8(2): 14. [In Slovak] PA

[1224] Bethlenfalvy E 1937: Die Tierwelt der Hohen Tatra. Tierbiologische Studien aus freier Wildbahn. Edmund Schustek, Spišské Podhradie, 113. SA 
[1225] Brinzík M 2003: Dravce a sovy ako objekty vtáčej kriminality na Slovensku [Raptors and owls as victim of bird crime in Slovakia], 20. In: Šutiaková T \& Brinzík M (eds), Zborník abstraktov $\mathrm{Z}$ odborného seminára "Spoločne proti vtáčej kriminalite" [Abstract proceedings from seminar "Against bird crime together"]. SOVS, Bratislava, 21. [In Slovak] CA

[1226] Brinzík M \& Uhrín J 2008: Dravé vtáky sú v nemilosti aj v období rozmnožovania a výchovy mlád'at [Raptors are disgraced also in breeding and young growing periods]. Vtáky Leto 2008: 12. [In Slovak] PA

[1227] Brtek V 1960: Poznajme naše pernaté dravce [Let's know our birds of prey]. Pol'ovníctvo a rybárstvo 12(3): 9. [In Slovak] PA

[1228] Burfield I 2008: The conservation status and trends of raptors and owls in Europe. Ambio 37(6): 401-407. SA

[1229] Cepák J \& Klvaňa P 2008: Zpráva Kroužkovací stanice Národního muzea Praha za rok 2007 [Report on Czech Bird Ringing for 2007]. Kroužkovatel 6: 1-52. [In Czech] RO

[1230] Cepák J \& Klvaňa P 2009: Zpráva Kroužkovací stanice Národního muzea Praha za rok 2008 [Report on Czech Bird Ringing for 2008]. Kroužkovatel 8: 1-24. [In Czech] RO

[1231] Chavko J 1992: Problematika ochrany dravcov na západnom Slovensku vo vzt'ahu k CHKO Malé Karpaty [Problems in protecting birds of prey in the Malé Karpaty Protected Landscape Area and in the greater western slovakian territory], 120-126. In: Hora J, Kaňuch P, Torn M, Safranek W, Pojer F, Přibylová D \& Hajný L (eds), Významná ptačí území v České a Slovenské republice. Sborník referátů ze semináŕe. Treboň, 24.-25. března 1992 [Important bird areas in Czech and Slovak Republics. Proceeding from seminar. Treboň, March 24-25, 1992]. Praha, Československé sekce ICBP, 175. [In Slovak with English summary] SA

[1232] Chavko J 1998: Protection of birds of prey in Slovakia. Enviromagazín 3(Extra Issue): 12. PA

[1233] Chavko J 1999: The Working Group on Research and Protection of Birds of Prey and Owls (SVODAS) - independent nongovernment organisation, which focuses on the research and protection of birds of prey and owls in the Slovak republic. Buteo Supplement: 43-44. RO

[1234] Chavko J 2003: SVODAS a jej súčinnost' pri riešení vtáčej kriminality na Slovensku [SVODAS and its play in bird crime solutions in Slovakia], 5-6. In: Šutiaková T \& Brinzík M (eds), Zborník abstraktov z odborného seminára "Spoločne proti vtáčej kriminalite" [Abstract proceedings from seminar "Against bird crime together"]. SOVS, Bratislava, 21. [In Slovak] CA

[1235] Chavko J 2005: Správy pracovných skupín [Reports of working groups]. Dravce a sovy 1(1): 6 . [In Slovak] RO

[1236] Chavko J 2006: In memoriam Petr Horák. Dravce a sovy 2(2): 36. [In Slovak with English summary] RO

[1237] Chavko J 2007: Súhrnná správa o výsledkoch monitoringu hniezdenia vybraných populácií dravých vtákov, vykonaných členmi občianskeho združenia Ochrana dravcov na Slovensku RPS v roku 2007 [Summary report on nesting monitoring of some raptor populations conducted by members of Raptor Protection in Slovakia - RPS in 2007]. Final report from 2007, 19. [Depon. in Raptor Protection of Slovakia - RPS, Bratislava]. [In Slovak] RO

[1238] Chavko J 2008: Dravce a $22 \mathrm{kV}$ elektrické vedenia [Birds of prey and $22 \mathrm{kV}$ power lines]. Dravce a sovy 4(2): 4-5. [In Slovak with English summary] RO

[1239] Chavko J 2008: Súhrnná správa o výsledkoch monitoringu hniezdenia vybraných populácií dravých vtákov, vykonaných členmi občianskeho združenia Ochrana dravcov na Slovensku RPS v roku 2008 [Summary report on nesting monitoring of some raptor populations conducted by members of Raptor Protection in Slovakia - RPS in 2008]. Final report from 2008, 20. [Depon. in Raptor Protection of Slovakia, Bratislava]. [In Slovak] RO

[1240] Chavko J 2009: História a súčasnost' riešenia problematiky ,stípov smrti“ - jedného z najväčších problémov ochrany dravcov [Solving problems of "pylons of death", the most important issue in raptors' protection - history and present state]. Ochrana prírody Slovenska 2009(1): 10-11. [In Slovak] PA

[1241] Cyprich D, Krumpál M \& Plachý J 2009: Hostitel'ské spektrum vtáčích druhov blich (Siphonaptera) rodov Ornithophaga Mikulin, Ceratophyllus Curtis a Dasypsyllus Baker na Slovensku [Host spectrum of bird fleas (Sipho- 
naptera) of the genera Ornithophaga Mikulin, Ceratophyllus Curtis and Dasypsyllus Baker in Slovakia]. Sylvia 45: 209-237. [In Slovak with English abstract] SA

[1242] Cyprich D, Krumpál M, Siryová S \& Karaska D 2006: Výskyt bích (Siphonaptera) v hniezdach dravcov a sov na Slovensku [Occurrence of fleas (Siphonaptera) in nests of raptors and owls in Slovakia]. Sylvia 42: 94-103. [In Slovak with English summary] SA

[1243] Čihák K s. a. [1985]: Pesticidy a dravci [Pesticides and raptors]. Skupina pro výzkum dravých ptáků a sov, Zprávy 5: 23-26. [In Czech with English summary] RO

[1244] Danko Š 1970: Vel'ký Milič, réserve d'oiseaux de proie en Slovaquie orientale. Bulletin Réserves Naturelles et Ornitologiques de Belgique 1970: 33-34. SA

[1245] Danko Š 1971: Dravé vtáctvo v rezervácii Vel'ký Milič na východnom Slovensku [Birds of prey in Vel'ký Milič Reserve in eastern Slovakia]. Ochrana fauny 5(1): 9-17. [In Slovak with English summary] SA

[1246] Danko Š 1976: Správa o činnosti Skupiny pre výskum dravého vtáctva a sov za r. 1975 [Report on activity of Group for Research of Birds of Prey and Owls in 1975]. Unpublished document, 8. [Depon. in Group for Research of Raptors and Owls, Michalovee]. [In Slovak] RO

[1247] Danko Š 1977: Správa o činnosti Skupiny pre výskum a ochranu dravcov a sov v ČSSR za roky 1975 a 1976 [Report on activity of Group for Rsearch and Protection of Birds of Prey and Owls in Czechoslovakia in 1975 and 1976], 93-104. In: Randík A (ed), Falconiana I. Súbor referátov zo seminára "Súčasný stav rozšírenia a ochrany dravých vtákov v Československu", Nitra, 24.-25. septembra 1976 [Falconiana I. Proceedings from seminar "Current state of distribution and protection of raptors in Czechoslovakia", Nitra, September 24-25, 1976]. Ústav experimentálnej fytopatológie a entomológie SAV, Sekcia ochrany fauny Slovenskej zoologickej spoločnosti SAV \& Sekcia ochrany vtáctva Československej ornitologickej spoločnosti, Bratislava, 107. [In Slovak with German summary] RO

[1248] Danko S 1977: Správa o činnosti Skupiny pre výskum dravého vtáctva a sov v ČSSR za rok 1976 [Report on activity of Group for Research of Birds of Prey and Owls in Czechoslovakia in 1975]. Unpublished document, 9. [Depon. in Group for Research of Raptors and Owls, Michalovce]. [In Slovak] RO

[1249] Danko Š 1978: Správa o činnosti Skupiny pre výskum dravého vtáctva a sov za rok 1977 [Report on activity of Group for Research of Birds of Prey and Owls in Czechoslovakia in 1977]. Unpublished document, 10. [Depon. in Group for Research of Raptors and Owls, Michalovce]. [In Slovak] RO

[1250] Danko Š 1979: Správa o činnosti za rok 1978 [Report on activity in 1978]. Unpublished document, 12. [Depon. in Group for Research of Raptors and Owls, Michalovce]. [In Slovak] RO

[1251] Danko Š 1980: Správa o činnosti za rok 1979 [Report on activity in 1979]. Unpublished document, 11. [Depon. in Group for Research of Raptors and Owls, Michalovce]. [In Slovak] RO

[1252] Danko Š s. a. [1981]: Správa o činnosti Skupiny pre výskum a ochranu dravých vtákov a sov v ČSSR za rok 1980 [Report on the Activity of the Group for Research of Birds of Prey and Owls in Czechoslovakia in 1980]. Skupina pro výzkum dravých ptáků a sov, Zprávy 1/80: 3-12. [In Slovak] RO

[1253] Danko Š s. a. [1982]: Správa o činnosti Skupiny pre výskum a ochranu dravého vtáctva a sov v ČSSR za rok 1981 [Report on the activity of the Group for Research and Protection of Birds of Prey and Owls in Czechoslovakia in 1981]. Skupina pro výzkum dravých ptáků a sov, Zprávy 2/81: 1-13. [In Slovak] RO

[1254] Danko Š s. a. [1983]: Správa o činnosti Skupiny pre výskum a ochranu dravého vtáctva a sov v ČSSR za rok 1982 [Report on the activity of the Group for Research and Protection of Birds of Prey and Owls in Czechoslovakia in 1982]. Skupina pro výzkum dravých ptáků a sov, Zprávy 3/82: 1-13. [In Slovak with English summary] RO

[1255] Danko Š s. a. [1984]: Pokyny na spracovanie výsledkov inventarizácie hniezdisk dravých vtákov a sov za obdobie rokov 1975-1984 [Instructions for processing of results from nesting sites of birds of prey and owls for period 1975-1984]. Skupina pro výzkum dravých ptáků a sov, Zprávy 4/83: 22. [In Slovak] RO

[1256] Danko Š s. a. [1984]: Predbežná správa o výsledkoch inventarizácie hniezdisk kane močiar- 
nej (Circus aeruginosus) a výra skalného (Bubo bubo) v ČSSR členmi SVDVS [Preliminary report on marsh harriers (Circus aeruginosus) and eagle owls (Bubo bubo) nesting sites inventory in Czechoslovakia conducted by SVDVS members]. Skupina pro výzkum dravých ptáků a sov, Zprávy 4/83: 18-21. [In Slovak] RO

[1257] Danko Š s. a. [1984]: Správa o činnosti Skupiny pre výskum a ochranu dravého vtáctva a sov v ČSSR za rok 1983 [Report on the activity of the Group for Research and Protection of Birds of Prey and Owls in Czechoslovakia in 1983]. Skupina pro výzkum dravých ptáků a sov, Zprávy 4/83: 1-15. [In Slovak with English summary] RO

[1258] Danko Š s. a. [1985]: Správa o činnosti Skupiny pre výskum a ochranu dravcov a sov v ČSSR za rok 1984 [Report on the activity of the Group for Research and Protection of Birds of Prey and Owls in Czechoslovakia in 1984]. Skupina pro výzkum dravých ptáků a sov, Zprávy 5/84: 1-20. [In Slovak with English summary] RO

[1259] Danko S̆ 1987: 10 rokov činnosti Skupiny pre výskum a ochranu dravcov a sov v ČSSR [10 years of activity of Group for Research and protection of Birds of Prey and Owls in Czechoslovakia], 39-54. In: Sitko J \& Trpák P (eds), Dravci 1985. Sborník z ornitologické konference Přerov 14.-16. 11. 1985 [Raptors 1985. Proceedings from ornithological conference Přerov, November 14-16, 1985]. Státní ústav památkové péče a ochrany př́rody ve spolupráci s Okresním vlastivědným muzeem J. Komenského, Moravským ornitologickým sdružením ve Státním změdělském nakladatelství, Přerov \& Praha, 252. [In Slovak] RO

[1260] Danko Š 1987: Správa o činnosti Skupiny pre výskum a ochranu dravcov a sov v ČSSR za rok 1985 [Report on the activity of the Group for Research and Protection of Birds of Prey and Owls in Czechoslovakia in 1985]. Skupina pro výzkum dravých ptáků a sov, Zprávy 6: 1-25. [In Slovak] RO

[1261] Danko Š 1988: Správa o činnosti Skupiny pre výskum a ochranu dravcov a sov v ČSSR za rok 1986 [Report on the activity of the Group for Research and Protection of Birds of Prey and Owls in Czechoslovakia in 1986]. Buteo 1[1986]: 3-31. [In Slovak with English summary] RO
[1262] Danko Š 1989: Správa o činnosti Skupiny pre výskum a ochranu dravcov a sov v ČSSR za rok 1987 [Report on the activity of the Group for Research and Protection of Birds of Prey and Owls in Czechoslovakia in 1987]. Buteo 2[1987]: 1-36. [In Slovak with English summary] RO

[1263] Danko Š 1989: Značkovanie dravcov na východnom Slovensku [Raptor marking in eastern Slovakia]. Buteo 2[1987]: 73-80. [In Slovak with English summary] RO

[1264] Danko S̆ 1990: Správa o činnosti Skupiny pre výskum a ochranu dravcov a sov v ČSSR za rok 1988 [Report on the activity of the Group for Research and Protection of Birds of Prey and Owls in Czechoslovakia in 1988]. Buteo 3[1988]: 1-34. [In Slovak with English summary] RO

[1265] Danko S̆ 1991: Správa o činnosti Skupiny pre výskum a ochranu dravcov a sov v ČSFR za rok 1989 [Report on the activity of the Group for Research and Protection of Birds of Prey and Owls in Czechoslovakia in 1989]. Buteo 4[1989]: 1-28. [In Slovak with English summary] RO

[1266] Danko Š 1992: Správa o činnosti Skupiny pre výskum a ochranu dravcov a sov v ČSFR za rok 1990 [Report on the Activity of the Group for Research and Protection of Birds of Prey and Owls in Czechoslovakia in 1990]. Buteo 5[1990]: 1-30. [In Slovak with English summary] RO

[1267] Danko Š 1994: Správa o činnosti Skupiny pre výskum a ochranu dravcov a sov v ČSFR za rok 1991 [Report on the Activity of the Group for Research and Protection of Birds of Prey and Owls in Czechoslovakia in 1991]. Buteo 6: 90-120. [In Slovak with English summary] RO

[1268] Danko Š 1994: Správa o činnosti Skupiny pre výskum a ochranu dravcov a sov v ČSFR za rok 1992 [Report on the activity of the Group for Research and Protection of Birds of Prey and Owls in Czechoslovakia in 1992]. Buteo 6: 121-151. [In Slovak with English summary] RO

[1269] Danko S̆ 2006: $\dagger$ JUDr. Willy Suetens (1930-2005). Dravce a sovy 2(2): 34-35. [In Slovak with English summary] RO

[1270] Danko Š, Darolová A \& Krištín A 2002: Rozšírenie vtákov na Slovensku [Birds Distribution in 
Slovakia]. Veda, Bratislava, 688. [In Slovak with English summaries] SA

[1271] Danko S, Diviš T, Dvorská J, Dvorský M, Chavko J, Karaska D, Kloubec B, Kurka P, Matušík H, Peške L, Schröpfer L \& Vacík R 1994: Stav poznatkov o početnosti hniezdnych populácií dravcov (Falconiformes) a sov (Strigiformes) v Českej a Slovenskej republike k roku 1990 a ich populačný trend $\mathrm{v}$ rokoch 1970-1990. The state of knowledge of breeding numbers of birds of prey (Falconiformes) and owls (Strigiformes) in the Czech and Slovak republics as of 1990 and their population trends in 1970-1990. Buteo 6: 1-89. SA

[1272] Danko Š, Chavko J \& Karaska D 1995: Správa o činnosti Skupiny pre ochranu dravcov a sov SOS za rok 1993 [Report on the activity of the Group on Protection of Birds of Prey and Owls in the Slovak republic in 1993]. Buteo 7: 109-121. [In Slovak with English summary] RO

[1273] Danko Š, Chavko J \& Karaska D 1995: Správa o činnosti Skupiny pre ochranu dravcov a sov SOS za rok 1994 [Report on the activity of the Group on Protection of Birds of Prey and Owls in the Slovak republic in 1994]. Buteo 7: 132-148. [In Slovak with English summary] RO

[1274] Danko Š, Chavko J \& Siryová S 2006: 30 rokov (1975-2004) existencie Skupiny pre výskum a ochranu dravcov a sov v (Česko)Slovensku ... alebo ako sme začínali a rozvíjali sa ... [30 years (1975-2004) of Group for Research and Protection of Raptors and Owls in (Czecho)Slovakia ... or, how we started and matured ...]. Dravce a sovy 2(2): 4-12. [In Slovak] RO

[1275] Danko Š, Karaska D \& Chavko J 2000: Správa o činnosti Skupiny pre ochranu dravcov a sov Slovenskej ornitologickej spoločnosti za rok 1995 [Report on the activity of the Group on Protection of Birds of Prey and Owls of the Slovak Society for Ornithology in 1995]. Tichodroma 13: 227-250. [In Slovak with English summary] RO

[1276] Darolová A, 2011: Vtáky. Birds, 303-460. In: Anonymus (ed), Atlas druhov európskeho významu pre územia NATURA 2000 na Slovensku. The atlas of species of European interest for NATURA 2000 sites in Slovakia. Slovenské múzeum ochrany prírody a jaskyniarstva, Liptovský Mikuláš, 520. RO

[1277] Deutschová L 2009: RPS na podujatí „Deň Zeme $v$ ZSE“ [RPS on the "Earth Day in ZSE"].
Dravce a sovy 5(1): 33. [In Slovak with English summary] RO

[1278] Deutschová L 2009: Z databázy prípadov vtáčej kriminality [From the bird crime database]. Dravce a sovy 5(2): 8-9. [In Slovak with English summary] RO

[1279] Deutschová L 2010: Ekologizácia 22 kV vedení $\mathrm{v}$ rámci projektov [Ecological improvements of $22 \mathrm{kV}$ power lines within projects]. Dravce a sovy 6(1): 22. [In Slovak with English summary] RO

[1280] Deutschová L 2010: Na úvod [Preface]. Dravce a sovy 6(1): 3. [In Slovak] RO

[1281] Deutschová L 2012: 7. medzinárodná konferencia o ochrane orla král'ovského bude v Bratislave [7th international conference on the conservation of imperial eagle will be held in Bratislava]. Dravce a sovy 8(2): 13. [In Slovak with English summary] RO

[1282] Deutschová L 2012: Milí dravčiarski priatelia, ... [Dear raptors' friends]. Dravce a sovy $8(1)$ : 3. [In Slovak] RO

[1283] Deutschová L 2012: Nová metóda ochrany vtáctva na Slovensku [New method of bird protection in Slovakia]. Dravce a sovy 8(2): 12. [In Slovak with English summary] RO

[1284] Deutschová L 2012: Nový slovensko-mad'arský projekt [Translated title]. Dravce a sovy $8(2)$ : 25. [In Slovak] RO

[1285] Deutschová L \& Chavko J s. a. [2010]: Vtáčia kriminalita a iná nelegálna činnost', ktorej obet'ou sú vtáky [Bird crime and other illegal activity victimized birds]. Ochrana dravcov na Slovensku, Bratislava, 16. [In Slovak] RO

[1286] Diviš T s. a. [1981]: Význam a úloha krajových podskupin Skupiny pre výzkum dravých ptáků a sov [Importance and role of county subgroups of Group for Research of Birds of Prey and Owls]. Skupina pro výzkum dravých ptáků a sov, Zprávy 1/80: 2. [In Czech] RO

[1287] Dravecký M 2007: Slovak Raptor Journal. Príhovor vedúceho redaktora [Slovak Raptor Journal. Editor in chief preface]. Dravce a sovy 3(2): 21-22. [In Slovak with English summary] RO

[1288] Dravecký M 2009: Tri ročníky Slovak Raptor Journal [Three volumes of Slovak Raptor Journal]. Dravce a sovy 5(1): 33. [In Slovak] RO

[1289] Dravecký M 2010: Book review. Slovak Raptor Journal 4: 102. DOI: 10.2478/v10262-012-00502. RO 
[1290] Dravecký M 2012: Ďalšie číslo Slovak Raptor Journal - SRJ 5/2011 [New issue of the Slovak Raptor Journal - SRJ 5/2011]. Dravce a sovy 8(2): 26. [In Slovak with English summary] RO

[1291] Dubravský A 2007: Stanislav Harvančík: Dravé vtáky Slovenska vo fotografii. Krátke zhodnotenie publikácie a jej význam pre slovenskú ornitologickú verejnost' [Birds of prey of Slovakia in pictures. Short book review and its importance for Slovak ornithological community]. Vtáky 2(4): 15. [In Slovak] RO

[1292] Fekete L \& Randík A 1977: K problematike sokoliarstva a ochrany dravých vtákov v niektorých štátoch Európy [To falconry and birds of prey protection in some European countries], 75-79. In: Randík A (ed), Falconiana I. Súbor referátov zo seminára "Súčasný stav rozšírenia a ochrany dravých vtákov v Československu", Nitra, 24.-25. septembra 1976 [Falconiana I. Proceedings from seminar "Current state of distribution and protection of raptors in Czechoslovakia", Nitra, September 24-25, 1976]. Ústav experimentálnej fytopatológie a entomológie SAV, Sekcia ochrany fauny Slovenskej zoologickej spoločnosti SAV \& Sekcia ochrany vtáctva Československej ornitologickej spoločnosti, Bratislava, 107. [In Slovak with German summary] SA

[1293] Fekete L \& Randík A 1978: K problematike sokoliarstva a ochrany dravých vtákov v niektorých štátoch Európy [To falconry and birds of prey protection in some European countries], 27. In: Sedláček K \& Pecina P (eds), Sborník referátů a př́íspěvků z celostátní pracovní porady "Dravci 1977", Davle u Prahy, 6.-9. 9. 1977. 1. díl [Proceedings from working meeting "Raptors 1977", Davle near Praha, September 6-9, 1977. Part 1]. Středisko státní památkové péče a ochrany přírody Středočeského kraje, Státní ústav památkové péče a ochrany př́rody \& Ústřední výbor Českého mysliveckého svazu, Brno, 106. [In Slovak] SA

[1294] Fekete L \& Vít'az V 1977: O výsledkoch pokusov s hniezdením dravcov $\mathrm{v}$ zajatí [Results of experiments on nesting of raptors in captivity], 51-52. In: Randík A (ed), Falconiana I. Súbor referátov zo seminára "Súčasný stav rozšírenia a ochrany dravých vtákov v Československu", Nitra, 24.-25. septembra 1976 [Falconiana I. Proceedings from seminar "Current state of dis- tribution and protection of raptors in Czechoslovakia", Nitra, September 24-25, 1976]. Ústav experimentálnej fytopatológie a entomológie SAV, Sekcia ochrany fauny Slovenskej zoologickej spoločnosti SAV \& Sekcia ochrany vtáctva Československej ornitologickej spoločnosti, Bratislava, 107. [In Slovak with English summary] SA

[1295] Fekete L \& Vít’az V 1978: O výsledkoch pokusov s hniezdením dravcov v zajatí [Results of experiments on nesting of raptors in captivity], 24-26. In: Sedláček K. \& Pecina P (eds), Sborník referátů a př́spěvků z celostátní pracovní porady "Dravci 1977", Davle u Prahy, 6.-9. 9. 1977. 1. díl [Proceedings from working meeting "Raptors 1977", Davle near Praha, September 6-9, 1977. Part 1]. Středisko státní památkové péče a ochrany prírody Středočeského kraje, Státní ústav památkové péče a ochrany prírody \& Ústřední výbor Českého mysliveckého svazu, Brno, 106. [In Slovak] SA

[1296] Ferianc O 1987: Slovenské mená dravcov (Falconiformes) sveta I [Slovak names of birds of prey (Falconiformes) of the world I]. Kultúra slova 21(5): 149-165. [In Slovak] RO

[1297] Ferianc O 1987: Slovenské mená dravcov (Falconiformes) sveta II [Slovak names of birds of prey (Falconiformes) of the world II]. Kultúra slova 21(10): 357-371. [In Slovak] RO

[1298] Formánek J \& Škopek J 1987: Přehled kroužkování dravců v ČSFR a jeho výsledky v letech 1934-84 [Outline of raptor ringing in Czechoslovakia and its results in 1934-84], 75-84. In: Sitko J \& Trpák P (eds), Dravci 1985. Sborník z ornitologické konference Přerov 14.-16. 11. 1985 [Raptors 1985. Proceedings from ornithological conference Přerov, November 14-16, 1985]. Státní ústav památkové péče a ochrany prírody ve spolupráci s Okresním vlastivědným muzeem J. Komenského, Moravským ornitologickým sdružením ve Státním změdělském nakladatelství, Přerov \& Praha, 252. [In Czech] RO

[1299] Formánek J \& Škopek J 1991: Výběr ze zahraničních zpětných hlášení došlých během roku 1989 [The choice from the recoveries of raptors, in-coming in the course of 1989]. Buteo 4[1989]: 29-32. [In Czech] RO

[1300] Hájek B 1997: K ochrane dravých vtákov $\mathrm{v}$ národných parkoch [To birds of prey protecti- 
on in national parks]. Národné parky 1997(2): 6. [In Slovak] PA

[1301] Hájek B, Dražil T, Divok F \& Leskovjanská A 2002: Realizácia praktickej starostlivosti o chránené územia a chránené druhy [Practical management of protected sites and species], 12-18. In: Divok F (ed), Ročenka 2000-2002 [Yearbook 2000-2002]. Státna ochrana prírody Slovenskej republiky, Správa Národného parku Slovenský raj, Spišská Nová Ves, 74. [In Slovak] RO

[1302] Hájek B \& Kormančík J 2008: Prierez činnost’ou na úseku ochrany živočíchov v NP Slovenský raj [Outline of activity in animal protection in Slovenský raj NP], 23-33. In: Divok F (ed), 20 rokov Národného parku Slovenský raj. Zborník príspevkov z konferencie. Čingov Hradisko 20.-21. 11. 2008 [20 years of Slovenský raj National Park. Conference proceedings. Čingov - Hradisko, November 20-21, 2008]. Štátna ochrana prírody SR, Správa NP Slovenský raj, Spišská Nová Ves, 132. [In Slovak] RO

[1303] Hapl E 2001: 3rd Euroasian conference of raptor research foundation, 80. In: Anonymus (ed), Ročenka Správy Národného parku Muránska planina 1999-2000. Správa NP Muránska planina, Revúca, 112. [In Slovak] RO

[1304] Hapl E 2006: Ochrana dravcov Muránskej planiny [Raptor protection in the Muránska planina Mts]. Reussia 3(2): 152. [In Slovak] CA

[1305] Haršáni L 1978: Ochrana dravcov a šeliem naliehavý problém súčasnosti [Raptors and other predators protection - present urgent problem]. Pamiatky - Príroda 1978(3): 14-17. [In Slovak] PA

[1306] Haršáni L \& Kaššák A 1997: Dravé vtáky. Súčasný stav ich ochrany [Birds of prey. Current state of their protection]. Pol'ovníctvo a rybárstvo 49(6): 6-7. [In Slovak] PA

[1307] Harvančík S 1977: Rozšírenie a ochrana dravcov a sov v okolí Partizánskeho [Distribution and protection of birds of prey and owls in surroundings of Partizánske town], 14-15. In: Randík A (ed), Falconiana I. Súbor referátov zo seminára "Súčasný stav rozšírenia a ochrany dravých vtákov v Československu", Nitra, 24.-25. septembra 1976 [Falconiana I. Proceedings from seminar "Current state of distribution and protection of raptors in Czechoslovakia", Nitra, September 24-25, 1976]. Ústav experimentálnej fytopatológie a entomológie SAV, Sekcia ochrany fauny Slovenskej zoologickej spoločnosti SAV \& Sekcia ochrany vtáctva Československej ornitologickej spoločnosti, Bratislava, 107. [In Slovak with German summary] SA

[1308] Harvančík S 1978: Rozšírenie a ochrana dravcov a sov v okolí Partizánskeho [Distribution and protection of birds of prey and owls in surroundings of Partizánske town], 13-14. In: Sedláček K \& Pecina P (eds), Sborník referátů a př́íspěvků z celostátní pracovní porady "Dravci 1977", Davle u Prahy, 6.-9. 9. 1977. 1. díl [Proceedings from working meeting "Raptors 1977", Davle near Praha, September 6-9, 1977. Part 1]. Středisko státní památkové péče a ochrany prírody Středočeského kraje, Státní ústav památkové péče a ochrany př́rody \& Ústřední výbor Českého mysliveckého svazu, Brno, 106. [In Slovak] SA

[1309] Harvančík S 1986: Dravce (Falconiformes) [Birds of prey (Falconiformes)], 113-129. In: Anonymus (ed), Možnosti SZOPK pri ochrane fauny SSR, Metodicko-námetová príručka č. 6 [Opprotunities of SZOPK in fanuna protection in Slovakia. Methodological guide no. 6]. ÚV SZOPK, Bratislava, 201. [In Slovak] RO

[1310] Harvančík S 1988: K problematike krúžkovania vzácnych dravcov [To ringing of rare birds of prey species]. Správy Slovenskej zoologickej spoločnosti SAV 14: 47-48. [In Slovak] RO

[1311] Harvančík S 1999: Stĺpy smrti stále aktuálne [Pylons of death still actual]. Vtáčie správy 6(1-2): 9. [In Slovak] PA

[1312] Harvančík S 2007: Dravé vtáky Slovenska vo fotografii. Birds of prey of Slovakia in pictures. Greifvögel der Slowakei im Bild. Dansta, Daniela Stanislavová, Prievidza, 96. RO

[1313] Hell P 1964: Príspevok k poznaniu potravy niektorých druhov dravcov a sov v mimoriadne tuhej zime 1962-1963 [Contribution to knowledge on diet of some raptors and owls in extremely cold winter 1962-1963]. Zoologické listy 13(3): 207-220. [In Slovak with German summary] SA

[1314] Hol'ma J 2003: Ochrana dravcov [Birds of prey protection]. Tatry 42(2): 2. [In Slovak] PA

[1315] Hrabár S 1904: Ragadozó madaraink tápláléka és szervezetök [Diet of our birds of prey and their organisms]. Természettudományi közlöny 36(418): 362-384. [In Hungarian] SA

[1316] Jamnický J 1999: Lov dravých vtákov (Falconi- 
formes a Accipitriformes) a sov (Strigformes) na Slovensku pred sto rokmi [Hunting on raptors (Falconiformes and Accipitriformes) and owls (Strigformes) in Slovakia hundred years ago]. Folia venatoria 28-29: 205-217. [In Slovak with German summary] SA

[1317] Jenei R 2010: Ponuka hniezd a ich využitie dravcami a sovami v pol'nohospodárskej krajine Podunajskej nížiny [Supply of nests and their use by raptors in an agricultural landscape of Podunajská nížina Lowland]. Tichodroma 22: 35-38. [In Slovak with English abstract] SA

[1318] Jirsík J 1941: Naši dravci. Pro lesní personál, lovce, rolníky, učitelstvo, ornithology a přátele prírody [Our raptors. For forestry staff, hunters, farmers, teachers, ornithologists and nature lovers]. Tiskem Otakara Janáčka, Praha, 220. [In Czech] SA

[1319] Kampf V 2008: Lovci s vtákmi [The hunters with birds]. Život 58(11. 10. 2008): 26-29. [In Slovak] PA

[1320] Karaska D 1986: Ochrana dravých vtákov v Československu [Birds of prey protection in Czechoslovakia]. Poznaj a chráń 6: 21. [In Slovak] PA

[1321] Karaska D 1998: Ornitologická konferencia „Dravci a sovy 1998“ Mikulov, Česká republika 18.-20. 9. 1998 [Ornitological conference „Birds of prey and owls 1998“ Mikulov, Czech Republic September 18-20, 1998]. Buteo 10: 163-164. [In Slovak] RO

[1322] Kaššák A 2003: Pohl'ad sokoliara a pol'ovníka na vtáčiu kriminalitu [Falconer's and hunter's view on bird crime], 11. In: Šutiaková $\mathrm{T} \&$ Brinzík M (eds), Zborník abstraktov z odborného seminára "Spoločne proti vtáčej kriminalite" [Abstract proceedings from seminar "Against bird crime together"]. SOVS, Bratislava, 21. [In Slovak] CA

[1323] Kicko J 2002: Denzita dravcov vo vybranom území [Birds of prey density in region under study], 25. In: Kropil R (ed), Aplikovaná ornitológia 2002. Zborník abstraktov zo 14. stredoslovenskej ornitologickej konferencie $\mathrm{s}$ medzinárodnou účastou konanej vo Zvolene 6.-7. septembra 2002 [Applied ornithology 2002. Abstract proceedings from 14th international ornithological conference in Zvolen, September 6-7, 2002]. Vydavatel'stvo Technickej univerzity, Zvolen, 29. [In Slovak] CA
[1324] Kicko J 2004: Niekol'ko redeterminácií dravcov zo zbierky Stredoslovenského múzea [Some reidentifications of birds of prey in collections of Museum of Central Slovakia]. Naturae Tutela 8: 211-212. [In Slovak] SA

[1325] Kicko J 2005: Výstava "Dravce Slovenska" ["Raptors of Slovakia" exhibition]. Dravce a sovy 1(1): 22. [In Slovak] PA

[1326] Kicko J 2008: Denzita a diverzita dravcov (Falconiformes) Žiarskej kotliny a Vtáčnika [Density and diversity of birds of prey (Falconiformes) in Žiarska kotlina Basin and Vtáčnik Mts]. Naturae Tutela 12: 131-137. [In Slovak with English abstract] SA

[1327] Korňan J 1997: Ochrana dravých vtákov na Slovensku [Birds of prey protection in Slovakia]. Národné parky 1997(2): 4-6. [In Slovak] PA

[1328] Korn̆an J \& Macek M 2011: Za Luckou ... [For Lucia ...]. Dravce a sovy 7(2): 26. [In Slovak] PA

[1329] Kovalik P, Topercer J \& Pačenovský S 2010: Odporúčané slovenské názvoslovie vtákov sveta [Recommended Slovak names of birds of the world]. Dravce a sovy 6(1): 33-36. [In Slovak] RO

[1330] Krajčovič I 2001: Dravce v l'udskej koži ohrozujú dravce [Predators in human skin threatenig raptors]. Národná obroda, Víkend 11(2. 6. 2001): VIII. [In Slovak] PA

[1331] Krištín A 1988: Modifikation des Bedeutungsindexes von Nahrungskomponenten und seine Verwendung. Biologia 43(10): 935-939. SA

[1332] Krištín A 1992: Význam bezstavovcov v potrave dravcov a sov [Importance of evrtebrates in diet of birds of prey and owls]. Zprávy MOS 50: 7-12. [In Slovak with German summary] SA

[1333] Kropil R 1998: Denzita dravcov v juhovýchodnej časti Kremnických vrchov $v$ rokoch 1996-1998 [Density of birds of prey in southeastern part of Kremnické vrchy Mts in 1996-1998], 19. In: Anonymus (eds), Ornitologická konference Dravci a sovy 1998. Mikulov, 18.-20. 9. 1998. Sborník abstraktů [Ornithological conference Raptors and owls 1998. Mikulov, September 18-20, 1998. Abstract proceedings]. Skupina pro ochranu a výzkum dravců a sov při České společnosti ornitologické, Mikulov, s. p. [28]. [In Slovak] CA

[1334] Kropil R \& Sládek J 1990: Príspevok k poznaniu potravy niektorých druhov dravcov a sov na 
Slovensku [On diet of some raptors and owls in Slovakia]. Biológia 45(10): 841-853. [In Slovak with English abstract and Russian summary] SA

[1335] Kukurugya S 1999: Stav a perspektívy rehabilitácie dravcov na Slovensku [Present state and perspectives of birds of prey rehabilitation in Slovakia]. Chránené územia Slovenska 42: 9-12. [In Slovak] RO

[1336] Kürthy A 2011: Spustenie akustického monitoringu na Slovensku [Acousting monitoring in Slovakia running], 16-17. In: Kropil R \& Lešo P (eds), Aplikovaná ornitológia 2011. Zborník abstraktov z 23. stredoslovenskej ornitologickej konferencie s medzinárodnou účast’ou konanej vo Zvolene 2. septembra 2011 [Applied ornithology 2011. Abstract proceedings from 23th international ornithological conference in Zvolen, September 2, 2011]. Vydavatel'stvo Technickej univerzity, Zvolen, 21. [In Slovak] CA

[1337] Lengyel J 2005: Odchyty dravcov a sov v Prírodnej rezervácii Žitavský luh (18.-22. 8. 2004) [Birds of prey and owls captures in Žitavský luh Nature Reserve (August 18-22, 2004)]. Dravce a sovy 1(1): 18-20. [In Slovak] SA

[1338] Lengyel J 2007: "Nezvyčajní" kamaráti... [“Unusual" friends]. Vtáky 2(4): 14. [In Slovak] PA

[1339] Lengyel J, Pavelčík P, Kukučka M \& Gúgh J 2006: "Sovia noc" ... alebo ako i obyčajné lucerkovisko môže byt' zaujímavé pre operence ["Owls night" $\ldots$ or why is an ordinary alfalfa stubble field good place for trapping]. Dravce a sovy 2(2): 26-27. [In Slovak with English summary] PA

[1340] Lešinský G 1997: Výskyt sov, dravcov a spevavcov $\mathrm{v}$ jaskyniach a priepastiach Slovenského krasu [Occurrence of owls, raptors and passerine birds in caves and abysses of Slovenský kras Mts]. Spravodaj Slovenskej speleologickej spoločnosti 48(4): 26-27. [In Slovak with English summary] SA

[1341] Lispuchová S 2000: Vzácne dravce zabité $\mathrm{z}$ l'udskej hlúposti [Due to human stupidity rare raptors killed]. Nový čas 10(22.1.2000): 12-13. [In Slovak] PA

[1342] Löbbová D \& Veselovský T 2011: Krátky pohl'ad do života na pasienku Kuchyňa [Short insight into life in the Kuchyña pasture]. Dravce a sovy 7(2): 7-9. [In Slovak with English summary] PA
[1343] López-López P, Bernavent-Corai J \& García-Ripollés C 2008: Geographical assemblages of European raptors and owls. Acta Oecologica 34: 252-257. DOI: http://dx.doi.org/10.1016/j.actao.2008.05.014. SA

[1344] Macek M 2007: Záchranná a rehabilitačná stanica v Zázrivej [Rescue and rehabilation station in Zázrivá]. Vtáky 2(3): 10-11. [In Slovak] RO

[1345] Madarász J 1884: Die Raubvögel Ungarns. Zeitschrift für die gesammte Ornithologie 1: 91-97. SA

[1346] Maderič B 1989: Výskyt dravých vtákov v CHKO Ponitrie a návrh opatrení na ich ochranu [Birds of prey occurrence in Ponitrie PLA and proposals for their protection]. Thesis, 118. [Depon. in Department of environmentalistics and microbiology, Agriculuture University, Nitra]. [In Slovak] QP

[1347] Maderič B 2008: Schválený Program rozvoja vidieka SR 2007-2013 [Rural Development Programme for 2007-2013 Slovakia approved]. Dravce a sovy 4(1): 26-27. [In Slovak with English summary] RO

[1348] Maderič B, Mikiara Š \& Pečenák V 1995: Výskum populačnej hustoty dravcov $\mathrm{v}$ západnej časti okresu Humenné [Research into the population density of birds of prey in the western part of Humenné district (Eastern Slovakia)]. Buteo 7: 169-172. [In Slovak with English summary] SA

[1349] Majda M 1997: Praktické skúsenosti z monitoringu a stráženia dravcov [Field experiences from birds of prey monitoring and guarding]. Národné parky 1(2): 26. [In Slovak] PA

[1350] Majko P 2001: Prichytenie českého sokoliara na Liptove [Czech falconer catched in the Liptov region]. Ochrana prírody Slovenska 2001(3): 10. [In Slovak] RO

[1351] Májsky J 1991: Ako d'alej s ochranou hniezd dravcov [How to protect raptors' nests in the future]. Chránené územia Slovenska 17: 51-52. [In Slovak] RO

[1352] Maroši I 1968: Sokoliarstvo a ochrana dravcov [Falconry and protection of birds of prey]. Ochrana fauny 2(3-4): 27-31. [In Slovak with Russian, English and German summaries] RO

[1353] Martinka J 1927: Sokoliarstvo na Slovensku [Falconry in Slovakia]. Slovenské pohl'ady 43(5): 308-320. [In Slovak] RO

[1354] Meyburg B-U \& Meyburg C 2008: Satellite tracking of raptors - how PTTs changed our lives. Tracker News 9(1): 2-5. SA 
[1355] Meyburg B-U \& Newton I 2010: Robin Chancellor $* 24$ October $1921-\dagger 27$ October 2010 . Slovak Raptor Journal 4: 132-133. DOI: 10.2478/v10262-012-0056-9. RO

[1356] Michal P 2003: Rehabilitácia pernatých dravcov [Rehabilitaion of birds of prey], 20. In: Šutiaková T \& Brinzík M (eds), Zborník abstraktov $\mathrm{Z}$ odborného seminára "Spoločne proti vtáčej kriminalite" [Abstract proceedings from seminar "Against bird crime together"]. SOVS, Bratislava, 21. [In Slovak] CA

[1357] Michal P 2003: Sokoliarstvo a jeho význam pri ochrane pernatých dravcov [Falconry and its importance for birds of prey protection], 10. In: Šutiaková T \& Brinzík M (eds), Zborník abstraktov z odborného seminára "Spoločne proti vtáčej kriminalite" [Abstract proceedings from seminar "Against bird crime together"]. SOVS, Bratislava, 21. [In Slovak] CA

[1358] Minka MS 2002: Stĺpy smrti postavili l'udia ["Pylons od death" were built by humans]. Moment 2002(17; 26. 4. 2002): 14-15. [In Slovak] PA

[1359] Mlynek V 2002: Krádež handicapovaných dravcov z Rehabilitačnej stanice $\mathrm{v}$ Nitre [Theft of handicapped raptors from Rehabilitation Station in Nitra]. Chránené územia Slovenska 53: 15-16. [In Slovak] RO

[1360] Moncman D 2007: Monitoring dravých vtákov $\mathrm{v}$ okolí Trnavy [Birds of prey survey in Trnava surroundings]. Vtáky 2(3): 14. [In Slovak] RO

[1361] Mošanský A 1953: Vzácnejšie druhy vtákov na východnom Slovensku [Rarer bird species in eastern Slovakia]. Sylvia 14: 109-110. [In Slovak] SA

[1362] Mošanský A 1962: Vplyv kultúrnej krajiny na nidobiológiu dravcov (Falconiformes) [Impact of cultural landscape on nesting biology of birds of prey (Falconiformes)], 117-124. In: Černý W \& Urbánek B (eds), Sborník přednášek II. celostátní konference ČSOS v Praze v červnu 1962 [Proceedings from II. national conference of ČSOS in Prague in June 1962]. ČOS, Národní museum, Praha, 166. [In Slovak and German] SA

[1363] Mrlík V \& Danko Š 1989: Stavy hnízdících párů dravců v Československu (stav k roku 1988) [Numbers of breeding pairs of raptors in Czechoslovakia in 1988]. Buteo 2[1987]: 37-40. [In Czech with English summary] SA

[1364] Mrlík V \& Danko Š 1990: Počty hnízdících párů dravců v Československu (stav k roku 1988) [Numbers of breeding pairs of raptors in Czechoslovakia in 1988]. Sylvia 27: 71-78. [In Czech with English summary] SA

[1365] Mucha F 2001: Dravec ide tvrdo na vec [Predator is acting strong]. Nový deň 2001(7. 9. 2001): 6. [In Slovak] PA

[1366] Murin B, Krištín A, Darolová A, Danko Š \& Kropil R 1994: Početnost' hniezdnych populácií vtákov na Slovensku [Breeding bird population sizes in Slovakia]. Sylvia 30(2): 97-105. [In Slovak with English abstract] SA

[1367] Nemček V 2008: Sčítanie dravcov na Záhorí [Census of birds of prey in Záhorie region (W Slovakia)]. Dravce a sovy 4(2): 22. [In Slovak with English summary] SA

[1368] Noga M 2005: Pamätám sa... [I remember ...]. Dravce a sovy 1(1): 3. [In Slovak] RO

[1369] Noga M 2005: Pár slov k členskej základni ... [Several words to members ...]. Dravce a sovy 1(1): 26. [In Slovak] RO

[1370] Noga M. 2005: Význam sledovania osteologických nálezov z potravy dravcov a sov [Importance of study of osteological records in diet of raptors and owls]. Final qualification paper, s. p. [Depon. in Department of ecology and environmentalistics, Faculty of natural sciences, Constantine the Philosopher University, Nitra]. [In Slovak] QP

[1371] Noga M 2007: Už sa zlietajú... [They arrived ...]. Dravce a sovy 3(2): 3. [In Slovak] RO

[1372] Noga M 2008: Kto striel'al na hniezda dravcov? [Who shooted on raptors' nests?]. Naše pol'ovníctvo 5(5): 8. [In Slovak] PA

[1373] Noga M 2008: Malé členské projekty [Small members'projects]. Dravce a sovy 4(2): 6. [In Slovak] RO

[1374] Noga M 2008: Na úvod [Preface]. Dravce a sovy 4(2): 3. [In Slovak] RO

[1375] Noga M 2008: [Neviem ako Vás...] [I do not know, ...]. Dravce a sovy 4(1): 3. [In Slovak] RO

[1376] Noga M 2009: Malé členské projekty - rok 2009 [Small members' projects - year 2009]. Dravce a sovy 5(2): 14. [In Slovak] RO

[1377] Noga M 2009: Na úvod [Preface]. Dravce a sovy 5(2): 3. [In Slovak] RO

[1378] Noga M 2009: Nálezom hniezda to všetko len začína [Finding the nest is just the beginning]. Dravce a sovy 5(2): 7. [In Slovak with English summary] RO 
[1379] Noga M 2009: Vedecká knižnica RPS [Scientific library of RPS]. Dravce a sovy 5(1): 32. [In Slovak] RO

[1380] Noga M 2010: Krúžkovanie - veda, vášeň, hobby? Rozhovor s vedúcimi krúžkovacích centrál v Českej a Slovenskej republike [Ringing - science, passion, hobby? Interview with managers of ringing centers in Czech and Slovak Republics]. Dravce a sovy 6(2): 4-7. [In Slovak] RO

[1381] Noga M 2010: Malé členské projekty - rok 2010 [Small members' projects - year 2010]. Dravce a sovy 6(1): 38. [In Slovak] RO

[1382] Noga M 2010: Na úvod [Preface]. Dravce a sovy 6(2): 3. [In Slovak] RO

[1383] Noga M 2011: Rok 2011 [Year 2011]. Dravce a sovy 7(2): 3. [In Slovak] RO

[1384] Noga M 2012: 19353 stípov [19353 pylons]. Dravce a sovy 8(2): 22-24. [In Slovak with English summary] RO

[1385] Noga M 2012: Malé členské projekty - rok 2012 [Small members' projects - year 2012]. Dravce a sovy 8(1): 25. [In Slovak] RO

[1386] Noga M 2012: Na úvod [Preface]. Dravce a sovy 8(2): 3. [In Slovak] RO

[1387] Noga M, Chavko J, Deutschová L, Maderič B \& Uhrin M 2009: Dravce v krajine. Cítanie nielen pre pol'ovníkov [Raptors in landscape. Reading not only for hunters]. Ochrana dravcov na Slovensku, Bratislava, 16. [In Slovak] RO

[1388] Noga M \& Vd'ačný A 2003: Majcichov (a okolie) - vystrel'ovanie hniezd [Majcichov (and surroundings) - shooting on nests], 20. In: Šutiaková T \& Brinzík M (eds), Zborník abstraktov z odborného seminára "Spoločne proti vtáčej kriminalite" [Abstract proceedings from seminar "Against bird crime together"]. SOVS, Bratislava, 21. [In Slovak] CA

[1389] Nuhličková S (ed) s. a.: Dravce a sovy Chráneného vtáčieho územia Vel'ká Fatra [Raptors and owls of Vel'ká Fatra Special Protection Area]. Ochrana dravcov na Slovensku, Bratislava, s. p. [16]. [In Slovak] RO

[1390] Nuhličková S (ed) s. a.: Dravce a sovy Chráneného vtáčieho územia Nízke Tatry [Raptors and owls of Nízke Tatry Special Protection Area]. Ochrana dravcov na Slovensku, Bratislava, s. p. [16]. [In Slovak] RO

[1391] Nuhličková S 2010: Nechajme dravce pokojne hniezdit! [Let them safely nest]. Vtáky 5(2): 12. [In Slovak] PA
[1392] Nuhličková S \& Maderič B s. a. [2010]: Dravce a sovy Chráneného vtáčieho územia Strážovské vrchy [Raptors and owls of Strážovské vrchy Special Protection Area]. Ochrana dravcov na Slovensku, Bratislava, s. p. [16]. [In Slovak] RO

[1393] Nuhličková S, Maderič B, Chavko J \& Lengyel J s. a. [2009]: Dravce Chráneného vtáčieho územia Dunajské luhy [Raptors and owls of Dunajské luhy Special Protection Area]. Ochrana dravcov na Slovensku, Bratislava, s. p. [16]. [In Slovak] RO

[1394] Nuhličková $S$, Maderič B \& Noga M s. a. [2009]: Dravce a sovy Chráneného vtáčieho územia Dolné Považie [Raptors and owls of Dolné Považie Special Protection Area]. Ochrana dravcov na Slovensku, Bratislava, s. p. [16]. [In Slovak] RO

[1395] Nuhličková $S$, Maderič B \& Noga $M$ s. a. [2009]: Dravce a sovy Chráneného vtáčieho územia Laborecká vrchovina [Raptors and owls of Laborecká vrchovina Special Protection Area]. Ochrana dravcov na Slovensku, Bratislava, s. p. [16]. [In Slovak] RO

[1396] Nuhličková S, Noga M \& Maderič B 2010: Dravce a sovy Chráneného vtáčieho územia Malé Karpaty [Raptors and owls of Malé Karpaty Special Protection Area]. Ochrana dravcov na Slovensku, Bratislava, s. p. [16]. [In Slovak] RO

[1397] Ondrišová J 2002: Vtáčie elektrické kreslá [Electric chairs for birds]. Slovenka 55(19): 26-27. [In Slovak] PA

[1398] Ostrihoň M \& Kropil R 2006: Diverzita a denzita dravcov (Accipitridae, Falconidae) v mimohniezdnom období vo Zvolenskej kotline [Diversity and density of birds of prey (Accipitridae, Falconidae) in Zvolenská kotlina Basin in non-breeding period], 46. In: Kropil R (ed), Aplikovaná ornitológia 2005 a 2006. Zborník abstraktov zo 17 . a 18 . stredoslovenskej ornitologickej konferencie $\mathrm{s}$ medzinárodnou účast'ou konanej vo Zvolene 15.-16. 9. 2005 a 8.-9. 9. 2006 [Applied ornithology 2005 and 2006. Abstract proceedings from 17th and 18th international ornithological conference in Zvolen, September 15-16, 2005 and September 8-9, 2006]. Technická univerzita Zvolen v spolupráci so ŠOP SR Banská Bystrica, Zvolen, 52. [In Slovak] CA

[1399] Ostrihoň M \& Kropil R 2006: Diverzita, denzita a preferencia habitatov dravcov (Accipitrifor- 
mes, Falconiformes) v mimohniezdnom období vo Zvolenskej kotline [Diversity, density and habitat preference of birds of prey (Accipitridae, Falconidae) in Zvolenská kotlina Basin in nonbreeding period], 13. In: Kropil R (ed), Aplikovaná ornitológia 2005 a 2006 . Zborník abstraktov zo 17 . a 18 . stredoslovenskej ornitologickej konferencie $\mathrm{s}$ medzinárodnou účastou konanej vo Zvolene 15.-16. 9. 2005 a 8.-9. 9. 2006 [Applied ornithology 2005 and 2006. Abstract proceedings from 17th and 18th international ornithological conference in Zvolen, September 15-16, 2005 and September 8-9, 2006]. Technická univerzita Zvolen v spolupráci so ŠOP SR Banská Bystrica, Zvolen, 52. [In Slovak] CA

[1400] Pčola Š 1980: Poznámky k hniezdeniu dravých vtákov v chránenej krajinnej oblasti Vihorlat [Notes to birds of prey nesting in the Vihorlat Protected Landscape Area]. Telekia 1: 9. [In Slovak] SA

[1401] Pecina P 1972: Dravce a sovy [Raptors and owls]. Pamiatky - Príroda 4(6): 31-33. [In Slovak] PA

[1402] Randík A 1968: K ochrane dravého vtáctva [On birds of prey protection]. Ochrana prírody 1: 25-26. [In Slovak] PA

[1403] Randík A 1972: Stavy dravého vtáctva v Československu [Numbers of birds of prey in Czechoslovakia]. Ochrana fauny 6(3): 144. [In Slovak] SA

[1404] Randík A 1977: Otvorenie seminára [Seminar opening], 9. In: Randík A (ed), Falconiana I. Súbor referátov zo seminára "Súčasný stav rozšírenia a ochrany dravých vtákov v Československu", Nitra, 24.-25. septembra 1976 [Falconiana I. Proceedings from seminar "Current state of distribution and protection of raptors in Czechoslovakia", Nitra, September 24-25, 1976]. Ústav experimentálnej fytopatológie a entomológie SAV, Sekcia ochrany fauny Slovenskej zoologickej spoločnosti SAV \& Sekcia ochrany vtáctva Československej ornitologickej spoločnosti, Bratislava, 107. [In Slovak] RO

[1405] Randík A 1977: Úvod [Preface], 5. In: Randík A (ed), Falconiana I. Súbor referátov zo seminára "Súčasný stav rozšírenia a ochrany dravých vtákov v Československu", Nitra, 24.-25. septembra 1976 [Falconiana I. Proceedings from seminar "Current state of distribution and protection of raptors in Czechoslovakia ", Nitra, September 24-25, 1976]. Ústav experimentálnej fytopatológie a entomológie SAV, Sekcia ochrany fauny Slovenskej zoologickej spoločnosti SAV \& Sekcia ochrany vtáctva Československej ornitologickej spoločnosti, Bratislava, 107. [In Slovak] RO

[1406] Randík A 1978: K výskytu a ochrane orliaka morského (Haliaëtus albicilla) a výrika obyčajného (Otus scops) na Slovensku [To occurrence and protection of white-tailed eagle (Haliaetus albicilla) and scops owl (Otus scops) in Slovakia], 22. In: Sedláček K \& Pecina P (eds), Sborník referátů a př́spěvků z celostátní pracovní porady "Dravci 1977", Davle u Prahy, 6.-9. 9. 1977. 1. díl [Proceedings from working meeting "Raptors 1977", Davle near Praha, September 6-9, 1977. Part 1]. Středisko státní památkové péče a ochrany prŕrody Středočeského kraje, Státní ústav památkové péče a ochrany př́rody \& Ústřední výbor Českého mysliveckého svazu, Brno, 106. [In Slovak] SA

[1407] Schön JT 2000: Sokoliari verzus inšpektori [Falconers verzus inspectors]. Národná obroda 10(9. 12. 2000): 22. [In Slovak] PA

[1408] Schröpfer L 2010: Book review. Slovak Raptor Journal 4: 114. DOI: 10.2478/v10262-012-0054y. RO

[1409] Skalová M 2007: XVI. Jarný ekofestival bol o ochrane dravcov na Slovensku [16th Spring ecofest was on raptor protection in Slovakia]. Castrum Novum 2007(9. 5. 2007): 8. [In Slovak] PA

[1410] Sládek J 1955: Ochrana dravých vtákov ako prírodných pamiatok [Protection of raptors as nature monuments]. Les 2(6): 124-139. [In Slovak] PA

[1411] Sládek J 1956: K problému ochrany dravých vtákov na Slovensku [On raptor protection in Slovakia], 49-52. In: Černý W \& Klíma M (eds), Sborník přednášek I. celostátní konference Československé ornithologické společnosti v Praze, v ř́inu 1956 [Proceedings from 1st national conference of Czechoslovak Ornithological Society in Prague, October 1956]. Československá ornithologická společnost \& Národní muzeum v Praze, Praha, 126. [In Slovak and German] RO

[1412] Sládek J 1961: Otvorený problém odstrelu per- 
natých dravcov [Problem of shooting of birds of prey still open]. Pol'ovníctvo a rybárstvo 13(7): 6. [In Slovak] PA

[1413] Sládek J 1969: K problematike ochrany dravých vtákov a sov [On raptors and owls protection]. Československá ochrana prírody 8: 193-207. [In Slovak with Russian and German summaries] RO

[1414] Sládek J 1970: K problematike ochrany dravých vtákov a sov [On raptors and owls protection]. Ochrana fauny 4(2): 88-89. [In Slovak] RO

[1415] Sládek J 1974: Problémy ochrany dravcov a sov v Československu [On raptors and owls protection problems in Czechoslovakia]. Zprávy Československé ornitologické společnosti 14: 3-6. [In Slovak] RO

[1416] Sládek J 1975: Štúdium sezónnych zmien v zložení potravy dravých vtákov ako základ ich ekologického a ekonomického hodnotenia [Studying seasonal changes in diet of raptors as basis for their ecological and economical evaluation]. Biológia 30(11): 853-859. [In Slovak with English and Russian abstracts] SA

[1417] Sládek J 1977: The status of birds of prey in Czechoslovakia, 87-91. In: Chancellor RD (ed), World Conference Birds of Prey Wienna, 1-3 October, 1975. Report of Proceedings. ICBP, Basingstoke, 442. RO

[1418] Sládek J 1977: Svetová konferencia ICBP o dravých vtákoch vo Viedni (1.-3. októbra 1975) [World birds of prey conference /ICBP/ in Wienna /1st-3rd October 1975/], 80-85. In: Randík A (ed), Falconiana I. Súbor referátov zo seminára "Súčasný stav rozšírenia a ochrany dravých vtákov v Československu", Nitra, 24.-25. septembra 1976 [Falconiana I. Proceedings from seminar "Current state of distribution and protection of raptors in Czechoslovakia", Nitra, September 24-25, 1976]. Ústav experimentálnej fytopatológie a entomológie SAV, Sekcia ochrany fauny Slovenskej zoologickej spoločnosti SAV \& Sekcia ochrany vtáctva Československej ornitologickej spoločnosti, Bratislava, 107. [In Slovak with English summary] RO

[1419] Sládek J 1980: Viete rozpoznávat' dravce? [Can you determine raptors?]. Pod Pol'anou, zpravodaj SZOPK 2: 23-26. [In Slovak] PA

[1420] Sládek J 1988: K histórii ochrany dravcov [On birds of prey protection history]. Správy
Slovenskej zoologickej spoločnosti SAV 14: 46. [In Slovak] RO

[1421] Sládek J 1992: K histórii ochrany dravcov na Slovensku [To birds of prey protection history in Slovakia]. Tichodroma 4: 117-119. [In Slovak with German summary] SA

[1422] Sládek J 1996: Doplnky ku histórii ochrany dravcov na Slovensku [Supplements to history of raptor protection in Slovakia]. Tichodroma 9: 175-184. [In Slovak with German summary] SA

[1423] Sládek J \& Hell P 1972: Problematika regulácie stavov dravcov, sov a krkavcovitých vtákov [Problems of regulating the populations of birds of prey, owls and Corvinae]. Ochrana fauny 6(4): 145-150. [In Slovak with English summary] SA

[1424] Sládek J \& Mošanský A 1957: Príspevok k výskytu a výžive zriedkavejších druhov dravých vtákov v posledných rokoch na Slovensku [On occurrence and diet of rarer raptors in last years in Slovakia]. Ochrana prírody 12(4): 110-116. [In Slovak with Russian and German summaries] SA

[1425] Slobodník V 2007: Nová publikácia do knižníc ochrancov aj obdivovatel'ov prírody [New publication for nature protectors and lovers]. Chránené územia Slovenska 73: 42. [In Slovak] PA

[1426] Slobodník V 2007: Summary of ringing project for raptors and owls in Slovakia from 2002 to 2004. Slovak Raptor Journal 1: 61-66. DOI: 10.2478/v10262-012-0013-7. RO

[1427] Slobodník V 2008: Summary on raptors and owls ringing in Slovakia in the period 2005-2006. Slovak Raptor Journal 2: 113-117. DOI: $10.2478 / \mathrm{v} 10262-012-0025-3$. RO

[1428] Slobodník V \& Slobodník R 2010: The summary on raptors and owls ringing in Slovakia in 2009. Slovak Raptor Journal 4: 109-113. DOI: 10.2478/v10262-012-0053-z. RO

[1429] Slobodník V \& Slobodník R 2011: Summary on raptors and owls ringing in Slovakia in the year 2010. Slovak Raptor Journal 5: 131-135. DOI: 10.2478/v10262-012-0060-0. RO

[1430] Slobodník V, Slobodník R \& Dravecký M 2009: Summary on raptors and owls ringing in Slovakia in 2007 and 2008. Slovak Raptor Journal 3: 63-72. DOI: 10.2478/v10262-012-0035-1. RO

[1431] Stanková E 2001: Dotazník o rehabilitácii dravcov a sov [Questionaire on raptors and owls rehabilitation]. Chránené územia Slovenska 49: 21. [In Slovak] RO 
[1432] Svobodová M 1997: Vícehostitelské kokcídie dravců a sov v České republice a ve Slovenské republice [Heteroxenous coccidia of raptors and owls from the Czech and Slovak Republics]. Buteo 9: 35-42. [In Czech with English summary] SA

[1433] Šášky M 2001: Sokoliari versus ministerstvo [Falconers verzus ministry]. Nový deň 2001(7. 11. 2001): 9. [In Slovak] PA

[1434] Šimák L \& Švehlík J 1978: Príspevok k ochrane dravcov a sov na východnom Slovensku [Contribution to birds of prey and owls protection in eastern Slovakia], 23. In: Sedláček K \& Pecina $\mathrm{P}$ (eds), Sborník referátů a př́spěvků z celostátní pracovní porady "Dravci 1977", Davle u Prahy, 6.-9. 9. 1977. 1. díl [Proceedings from working meeting "Raptors 1977", Davle near Praha, September 6-9, 1977. Part 1]. Středisko státní památkové péče a ochrany prrírody Středočeského kraje, Státní ústav památkové péče a ochrany prírody \& Ústřední výbor Českého mysliveckého svazu, Brno, 106. [In Slovak] RO

[1435] Šimončič A 1997: Operení predátori [Feathered predators]. Sme plus 31(50): 42-43. [In Slovak] PA

[1436] Škopek J \& Formánek J 1990: Výběr ze zahraničních zpětných hlášení došlých během roku 1988 [The choice from the recoveries of raptors, in-coming in the course of 1988]. Buteo 3[1988]: 35-38. [In Czech] RO

[1437] Škopek J \& Formánek J 1992: Výběr výsledků kroužkování dravců a sov v ČSFR (1990-1991) [Birds of prey and owls - selected recoveries from Czechoslovakia (1990-1991)]. Buteo 5[1990]: 31-36. [In English] RO

[1438] Šmelková V 2009: Monitoring dravcov využíva energiu slnka [Solar energy used in raptor monitoring]. Rol'nícke noviny 64(27. 3. 2009): 17. [In Slovak] PA

[1439] Št’astný K 1977: Stručné zhodnocení semináře [Short seminar evaluation], 87-88. In: Randík A (ed), Falconiana I. Súbor referátov zo seminára "Súčasný stav rozšírenia a ochrany dravých vtákov v Československu", Nitra, 24.-25. septembra 1976 [Falconiana I. Proceedings from seminar "Current state of distribution and protection of raptors in Czechoslovakia ", Nitra, September 24-25, 1976]. Ústav experimentálnej fytopatológie a entomológie SAV, Sekcia ochrany fauny Slovenskej zoologickej spoloč- nosti SAV \& Sekcia ochrany vtáctva Československej ornitologickej spoločnosti, Bratislava, 107. [In Slovak] RO

[1440] Švehlík J \& Šimák L 1977: Techniky zvyšovania počtu úspešných hniezdení a vyvedených mlád'at u niektorých druhov dravých vtákov a sov na východnom Slovensku [Number raising technics of succesfull breeding and raising youngs in some species of birds of prey and owls in Eastern Slovakia], 41-48. In: Randík A (ed), Falconiana I. Súbor referátov zo seminára "Súčasný stav rozšírenia a ochrany dravých vtákov v Československu", Nitra, 24.-25. septembra 1976 [Falconiana I. Proceedings from seminar "Current state of distribution and protection of raptors in Czechoslovakia", Nitra, September 24-25, 1976]. Ústav experimentálnej fytopatológie a entomológie SAV, Sekcia ochrany fauny Slovenskej zoologickej spoločnosti SAV \& Sekcia ochrany vtáctva Československej ornitologickej spoločnosti, Bratislava, 107. [In Slovak with English summary] RO

[1441] Švehlík J \& Šimák L 1978: Techniky zvyšovania počtu úspešných hniezdení a vyvedených mlád'at u niektorých druhov dravých vtákov a sov na východnom Slovensku [Techniques for increasing of numbers of successful nestings and numbers of fledglings in some raptor and owl species in eastern Slovakia], 20-21. In: Sedláček $\mathrm{K} \&$ Pecina $\mathrm{P}$ (eds), Sborník referátů a př́íspěvků z celostátní pracovní porady "Dravci 1977", Davle u Prahy, 6.-9. 9. 1977. 1. díl [Proceedings from working meeting "Raptors 1977", Davle near Praha, September 6-9, 1977. Part 1]. Středisko státní památkové péče a ochrany přírody Středočeského kraje, Státní ústav památkové péče a ochrany př́rody \& Ústřrední výbor Českého mysliveckého svazu, Brno, 106. [In Slovak] RO

[1442] Trnka A \& Prokop P 2006: Do predators cause a change in passerine movement patterns as indicated by mist-net trapping rates? Ardea 94(1): 71-76. SA

[1443] Turis P 1990: Záverečná správa o sledovaní dravcov na území CHKO Muránska planina do r. 1990 [Report on birds of prey survey in Muránska planina PLA to 1990]. Unpublished manuscript, 7. [Depon. in Muránska planina PLA Administration, Revúca]. [In Slovak] RO 
[1444] Tužinský J 1998: Dravce (Falconiformes) na vybranom území Školského lesného podniku Technickej univerzity vo Zvolene [Raptors (Falconiformes) in School Forest Company of Technical University in Zvolen]. Thesis. [Depon. in Technical University, Zvolen]. [In Slovak] QP

[1445] Uhrin M 2008: Ochrana dravcov na Slovensku bude mat' vlastnú knižnicu. [Raptor Protection will have own library]. Dravce a sovy 4(2): 19. [In Slovak] RO

[1446] Uhrin M 2009: Spolupráca s mad’arskými partnermi na východnom Slovensku [Cooperation with Hungarian partners in eastern Slovakia]. Dravce a sovy 5(2): 22. [In Slovak with English summary] RO

[1447] Uhrin M 2010: Book review. Slovak Raptor Journal 4: 44. DOI: 10.2478/v10262-012-00440 . RO

[1448] Uhrin M 2010: Book review. Slovak Raptor Journal 4: 82. DOI: 10.2478/v10262-012-0047X. RO

[1449] Uhrinová D 2003: Počty vykradnutých hniezd na Slovensku sa z roka na rok zvyšujú [Number of robbery nests in Slovakia annually increasing]. Ochrana prírody Slovenska 2003(2): 27. [In Slovak] RO

[1450] Urban F 1985: Ještě k ochraně dravců [Still on raptor protection]. Památky a príroda 2: 120. [In Czech] PA

[1451] Varga J 1984: K niektorým problémom praktického zabezpečenia ochrany dravých vtákov na Slovensku [To some problems of practical protection of birds of prey in Slovakia], 167-169. In: Vartíková E (ed), Problémy a otázky ochrany flóry a fauny SSR. X. celoslovenský seminár [Problems and questions of flora and fauna protection in Slovakia. 10th national seminar]. ÚV SZOPK, Bratislava, 217. [In Slovak] SA

[1452] Vician V \& Balaška V 2004: Dravé vtáky v Štiavnických vrchoch [Birds of prey in Štiavnické vrchy Mts]. Chránené územia Slovenska 60: 33-35. [In Slovak] PA

[1453] Vlachovičová M 2010: Dravce nížinnej pol'nohospodárskej krajiny JZ Slovenska [Raptors of lowland agricultural landscape in SW Slovakia], 55. In: Stloukal E (ed), Zborník abstraktov z konferencie 16. Feriancove dni 2010, Bratislava, 9.-10. 12. 2010 [Abstract procee- dings from conference 16th Ferianc days 2010, Bratislava, December 9-10, 2010]. Faunima, Bratislava, 62. [In Slovak] CA

[1454] Voskár J 1976: Populačná hustota a ochrana dravých vtákov na východnom Slovensku od roku 1965 do roku 1973 [Population density and protection of raptors in eastern Slovakia in 1965-1973]. Pol'ovnícky zborník 5-6: 368-397. [In Slovak with Russian, German and Hungarian summaries] SA

[1455] Voskár J 1977: Súčasné stavy, populačná hustota a ochrana dravých vtákov na východnom Slovensku [Current numbers, population density and protection of raptors in eastern Slovakia], 21-22. In: Randík A (ed), Falconiana I. Súbor referátov zo seminára "Súčasný stav rozšírenia a ochrany dravých vtákov v Československu", Nitra, 24.-25. septembra 1976 [Falconiana I. Proceedings from seminar "Current state of distribution and protection of raptors in Czechoslovakia ", Nitra, September 24-25, 1976]. Ústav experimentálnej fytopatológie a entomológie SAV, Sekcia ochrany fauny Slovenskej zoologickej spoločnosti SAV \& Sekcia ochrany vtáctva Československej ornitologickej spoločnosti, Bratislava, 107. [In Slovak and German] SA

[1456] Voskár J 1978: Populačná hustota a ochrana dravých vtákov na východnom Slovensku v letech 1965-1973 [Population density and protection of raptors in eastern Slovakia in 1965-1973], 71-72. In: Sedláček K \& Pecina P (eds), Sborník referátů a př́spěvků z celostátní pracovní porady "Dravci 1977", Davle u Prahy, 6.-9. 9. 1977. 1. díl [Proceedings from working meeting "Raptors 1977", Davle near Praha, September 6-9, 1977. Part 1]. Středisko státní památkové péče a ochrany př́rody Středočeského kraje, Státní ústav památkové péče a ochrany prírody \& Ústřední výbor Českého mysliveckého svazu, Brno, 106. [In Slovak] SA

[1457] Voskár J 1978: Súčasné stavy, populačná hustota a ochrana dravých vtákov na východnom Slovensku [Current numbers, population density and protection of raptors in eastern Slovakia], 16. In: Sedláček K \& Pecina P (eds), Sborník referátů a př́íspěvků z celostátní pracovní porady "Dravci 1977", Davle u Prahy, 6.-9. 9. 1977. 1. díl [Proceedings from working meeting "Raptors 1977", Davle near Praha, September 6-9, 1977. Part 1]. Středisko státní památkové péče 
a ochrany prŕrody Středočeského kraje, Státní ústav památkové péče a ochrany prírody \& Ústřední výbor Českého mysliveckého svazu, Brno, 106. [In Slovak] SA

[1458] Votýpka J, Lukeš J \& Oborník M 2004: Phylogenetic relationship of Trypanosoma corvi with other avian trypanosomes. Acta Protozoologica 43: 225-231. SA

[1459] Votýpka J, Oborník M, Volf P, Svobodová M \& Lukeš J 2002: Trypanosoma avium of raptors (Falconiformes): Phylogeny and identification of vectors. Parasitology 125(3): 253-263. SA

[1460] Zuskin J 2002: Súhrnná správa o výsledkoch výskumu SVODAS za rok 2001 [Summary report on research activity of SVODAS in 2001]. Chránené územia Slovenska 51: 23-24. [In Slovak] RO

[1461] Zuskinová M 1996: Ochrana dravcov na Slovensku [Raptor protection in Slovakia]. Informačný bulletin, SAŽP Banská Bystrica 2(4): 16-17. [In Slovak] RO

[1462] Zuskinová M \& Majko P 1998: Slovakia in the struggle against the illegal trade in birds of prey. Enviromagazín 3(Extra Issue): 13. PA

A c c i p it rifor m e s

[1463] Ballo P \& Sýkora J 2005: Monitoring kolónií svišt’a vrchovského tatranského v Západných Tatrách. Úsek Sivý vrch - Baníkov [Monitoring of Tatra marmot colonies in Západné Tatry Mts. Sivý vrch Mt - Baníkov Mt section], 61-76. In: Šubová D (ed), Medzinárodná konferencia prírodovedných pracovníkov múzeí a pracovníkov múzeí v prírode. 24.-25. 5. 2005. Zborník referátov [International conference of workers of Natural History and Open Air Museums. May 24-25, 2005. Proceedings]. Slovenské múzeum ochrany prírody a jaskyniarstva, Liptovský Mikuláš, 80. [In Slovak] SA

[1464] Ballo P \& Sýkora J 2006: Monitoring kolónií svišt'a vrchovského tatranského $\mathrm{v}$ Západných Tatrách. Úsek Baníkov - Ostrý Roháč [Monitoring of Tatra marmot colonies in Západné Tatry Mts. Baníkov Mt - Ostrý Roháč Mt section], 61-74. In: Šubová D (eds), Medzinárodná konferencia prírodovedných pracovníkov múzeí a pracovníkov múzeí v prírode. 23.-25. 5. 2006. Zborník referátov [International conference of workers of Natural History and Open Air Museums. May 23-25,
2006. Proceedings]. Slovenské múzeum ochrany prírody a jaskyniarstva, Liptovský Mikuláš, 80. [In Slovak] SA

[1465] Baum J 1937: Ornithologická pozorování v Tatrách [Ornithological notes from the Tatra Mountains]. Sylvia 2: 29-33. [In Czech with English summary] SA

[1466] Beniska B \& Šotnár K 2010: Myšiak hôrny (Buteo buteo) [Common buzzard (Buteo buteo)]. Dravce a sovy 6(1): 16. [In Slovak] SA

[1467] Bethlenfalvy E 1955: A szirtisas hangya-fogyasztása. Golden eagle feeding on ants. Aquila 59/62: 398-399, 451. SA

[1468] Bielikova M, Ficek A, Valkova D \& Turna J 2010: Multiplex PCR amplification of 13 microsatellite loci for Aquila chrysaetos in forensic applications. Biologia 65(6): 1081-1088. DOI: 10.2478/s11756-010-0112-9. SA

[1469] Bohuš M 2007: Konferencia o orliakoch morských "The white-tailed eagle in the heart of Europe" [Conference "The white-tailed eagle in the heart of Europe"]. Vtáky 2(4): 3. [In Slovak] RO

[1470] Bohuš M 2011: Sčítanie zimujúcich orliakov morských na slovenskom úseku Dunaja $\mathrm{v}$ zimách 2008/2009 až 2010/2011 [Census of wintering white-tailed eagles in Slovak section of the Danube River in winters 2008/2009 2010/2011]. Tichodroma 23: 53-56. [In Slovak with English abstract] SA

[1471] Bohuš M, Lengyel J \& Rác P 2009: The whitetailed eagle (Haliaeetus albicilla) in Slovakia. Denisia 27: 79-83. SA

[1472] Bohuš M, Rác P, Lengyel J \& Váczi M 2009: Správa zo siedmeho sčítania zimujúcich orliakov morských na Dunaji [Report from seventh census of white-tailed eagles on the Danube River]. Dravce a sovy 5(1): 22. [In Slovak with English summary] SA

[1473] Bohuš M \& Ridzoň J 2007: Sčítanie orliakov na Dunaji. 26. január 2008 [White-tailed eagle census on Danube. January 26, 2008]. Vtáky 2(4): 17. [In Slovak] PA

[1474] Čalkovský M, Korňan M \& Macek M 2011: Potrava orla skalného (Aquila chrysaetos) počas hniezdenia $\mathrm{v}$ podmienkach Slovenska: analýza videozáznamov z monitoringu hniezda [Diet of nesting golden eagle (Aquila chrysaetos) in Slovakia: analysis of videorecordings from nest monitoring], 13-14. In: Kropil R \& Lešo P (eds), Aplikovaná ornitológia 2011. Zborník abstraktov 
z 23. stredoslovenskej ornitologickej konferencie $\mathrm{s}$ medzinárodnou účast’ou konanej vo Zvolene 2. septembra 2011 [Applied ornithology 2011. Abstract proceedings from 23th international ornithological conference in Zvolen, September 2, 2011]. Vydavatel'stvo Technickej univerzity, Zvolen, 21. [In Slovak] CA

[1475] Chavko J 2009: Orliak morský (Haliaeetus albicilla). Správa za rok 2008 [White-tailed eagle (Haliaeetus albicilla). Report from 2008]. Dravce a sovy 5(1): 9. [In Slovak] RO

[1476] Chavko J 2009: Orol král'ovský (Aquila heliaca). Správa za rok 2008 [Eastern imperial eagle (Aquila heliaca). Report from 2008]. Dravce a sovy 5(1): 7. [In Slovak] RO

[1477] Chavko J 2010: Orliak morský (Haliaeetus albicilla) [White-tailed eagle (Haliaeetus albicilla)]. Dravce a sovy 6(1): 6. [In Slovak] RO

[1478] Chavko J 2010: Orol král'ovský (Aquila heliaca) [Eastern imperial eagle (Aquila heliaca)]. Dravce a sovy 6(1): 4. [In Slovak] RO

[1479] Chavko J 2012: Orliak morský (Haliaeetus albicilla) [White-tailed eagle (Haliaeetus albicilla)]. Dravce a sovy 8(1): 7. [In Slovak] RO

[1480] Chavko J \& Danko Š 2012: Orol král'ovský (Aquila heliaca) [Eastern imperial eagle (Aquila heliaca)]. Dravce a sovy 8(1): 6. [In Slovak] RO

[1481] Danko Š 2008: Orel královský. Aquila heliaca. Orol král'ovský. Imperial eagle, 155-157. In: Cepák J, Klvaňa P, Škopek J, Schröpfer L, Jelínek M, Hořák D, Formánek J \& Zárybnický J (eds), Atlas migrace ptáků České a Slovenské republiky. Czech and Slovak bird migration atlas. Aventinum, Praha, 608. [In Slovak with English summary] SA

[1482] Danko Š 2008: Orel křiklavý. Aquila pomarina. Orol krikl'avý. Lesser spotted eagle, 284-286. In: Cepák J, Klvaňa P, Škopek J, Schröpfer L, Jelínek M, Hořák D, Formánek J \& Zárybnický J (eds), Atlas migrace ptáků České a Slovenské republiky. Czech and Slovak bird migration atlas. Aventinum, Praha, 608. [In Slovak with English summary] SA

[1483] Danko Š 2008: Orel skalní. Aquila chrysaetos. Orol skalný. Golden eagle, 286-287. In: Cepák J, Klvaňa P, Škopek J, Schröpfer L, Jelínek M, Hořák D, Formánek J \& Zárybnický J (eds), Atlas migrace ptáků České a Slovenské republiky. Czech and Slovak bird migration atlas. Aventinum, Praha, 608. [In Czech with English summary] SA
[1484] Danko Š 2010: Hadiar krátkoprstý (Circaetus gallicus) [Short-toed snake eagle (Circaetus gallicus)]. Dravce a sovy 6(1): 7. [In Slovak] SA

[1485] Danko S̆, Chavko J, Demeter G, Mihók J, Izakovič J, Latková $\mathrm{H}$, Siryová $\mathrm{S}$, Noga $\mathrm{M} \& \mathrm{Ne}-$ mček V 2011: Conservation of eastern imperial eagle in the Slovak part of the Carpathian Basin - Results of the EU LIFE-Nature project (2003-2007). Acta Zoologica Bulgarica Supplementum 3: 71-78. SA

[1486] Deutschová L 2012: Orol, ktorý prežil zásah elektrickým prúdom, sa vrátil do prírody [Eagle survived electrocution and returned to the wild]. Dravce a sovy 8(2): 8-9. [In Slovak with English summary] PA

[1487] Dravecký M 2009: Orol krikl'avý (Aquila pomarina). Správa za rok 2008 [Lesser spotted eagle (Aquila pomarina). Report from 2008]. Dravce a sovy 5(1): 8. [In Slovak] SA

[1488] Dravecký M 2010: Orol krikl’avý (Aquila pomarina) [Lesser spotted eagle (Aquila pomari$n a)$ ]. Dravce a sovy 6(1): 5. [In Slovak] SA

[1489] Dravecký M 2012: Orol krikl'avý (Aquila pomarina) [Lesser spotted eagle (Aquila pomari$n a)$ ]. Dravce a sovy 8(1): 4-5. [In Slovak] SA

[1490] Dravecký M, Sellis U, Bergmanis U, Dombrovski V, Lontkowski J, Maciorowski G, Maderič B, Meyburg B-U, Mizera T, Stój M, Treinys R \& Wójciak J 2008: Colour ringing of the Spotted Eagles (Aquila pomarina, Aquila clanga and their hybrids) in Europe - a review. Slovak Raptor Journal 2: 37-52. DOI: 10.2478/v10262-0120017-3. SA

[1491] Dubravský A 2009: Bol som členom orlej rodiny [I was member of eagle family]. Dravce a sovy 5(1): 24-25. [In Slovak with English summary] PA

[1492] Eck S 1982: Weiter Untersuchungen an Accipiter gentilis gallinarum (Brehm, 1827) (Aves, Accipitriformes, Accipitridae). Zoologische Abhandlungen aus dem Staatliches Museum für Tierkunde in Dresden 38(3): 65-82. SA

[1493] Guziová Z, Maderič B \& Dravecký M 2011: Európska komisia podporuje ochranu populácie orla krikl'avého (Aquila pomarina) v Slovenskej republike [Conservation of the population of lesser spotted eagle in Slovak republic is supported by the European Commision]. Dravce a sovy 7(2): 4-6. [In Slovak with English summary] PA 
[1494] Harvančík S 2001: Prvé vtáky slovenskými krúžkami okrúžkované [First birds ringed with Slovak rings]. Ochrana prírody Slovenska 2001(4): 11. [In Slovak] RO

[1495] Harvančík S, Šnírer L, Siklienka R, Demeter G \& Dubravský A 2008: Hniezdenie orla král'ovského (Aquila heliaca) v územnej pôsobnosti Správy Chránenej krajinnej oblasti Ponitrie v rokoch 2003-2007 [Eastern imperial eagle (Aquila heliaca) nesting in operational area of Ponitrie Protected Landscape Area Administration in 2003-2007]. Rosalia 19: 203-208. [In Slovak with English abstract] SA

[1496] Hatinová M 2008: Orol skalný - král' vtákov a vták král'ov [Golden eagle - king of birds and bird of kings]. Sinter 16: 31. [In Slovak] PA

[1497] von Hetzendorf E 1894: Steinadler in Ober-Ungarn. Ornithologisches Jahrbuch 5(2): 77-78. SA

[1498] Honnen A-C, Hailer F, Kenntner N, Literák I, Dubská L \& Zachos FE 2010: Mitochondrial DNA and nuclear microsatellites reveal high diversity and genetic structure in an avian top predator, the white-tailed sea eagle, in central Europe. Biological Journal of the Linnean Society 99: 727-737. DOI: 10.1111/j.10958312.2010.01373.x. SA

[1499] Izakovič A 2012: Výskyt kane sivej (Circus cyaneus) $\mathrm{v}$ hniezdnom období pri Bratislave [Occurrence of the northern harrier (Circus cyaneus) in breeding period near Bratislava city]. Dravce a sovy 8(2): 7. [In Slovak with English summary] SA

[1500] Kaňuščák P 2012: Výskyt orliaka morského na Síňave a v širšom okolí Piešt'an [Occurrence of white-tailed eagle in Síňava and in Piešt'any surroundings]. Vtáky 7(1): 9. [In Slovak] PA

[1501] Kicko J 2008: Monitoring a ochrana orla krikl'avého (Aquila pomarina) na strednom Slovensku [Monitoring and conservation of the lesser spotted eagle in Slovakia]. Dravce a sovy 4(2): 7. [In Slovak with English summary] SA

[1502] Kicko J 2010: Aj orly krikl'avé sú predmetom vykrádania [Lesser spotted eagles also subject of robbery]. Dravce a sovy 6(1): 37. [In Slovak] RO

[1503] Kicko J 2010: Ako hl'adat' krúžkované jedince v populácii orla krikl'avého? Stav prekrúžkovania populácie orlov krikl'avých na Liptove a Pohroní [How to search for ringed specimens in the lesser spotted eagle population?]. Dravce a sovy 6(2): 12-13. [In Slovak with English summary] RO
[1504] Kicko J 2010: Stav prekrúžkovania populácie orla krikl’avého - prvé skúsenosti a výsledky [Number of ringed birds in population of lesser spotted eagles - first experiences and results], 35. In: Stloukal E (ed), Zborník abstraktov z konferencie 16. Feriancove dni 2010, Bratislava, 9.-10. 12. 2010 [Abstract proceedings from conference 16th Ferianc days 2010, Bratislava, December 9-10, 2010]. Faunima, Bratislava, 62. [In Slovak] CA

[1505] Kicko J \& Devečka V 2010: Prípady zranení a vrodená vada u orla krikl'avého (Aquila pomarina) z roku 2009 [Cases of injury and inborn disability in the lesser spotted eagle (Aquila pomarina) in 2009]. Tichodroma 22: 95-96. [In Slovak] SA

[1506] Kicko J \& Vrlík P 2009: Početnost' orla krikl'avého (Aquila pomarina) v Národnom parku Nízke Tatry a niektoré zaujímavosti z biológie a ekológie druhu [Abundance of lesser spotted eagles (Aquila pomarina) in Nízke Tatry National Park and some notes to species biology and ecology], 207-212. In: Turis P \& Vidlička L' (eds), Príroda Nízkych Tatier 2. Zborník referátov a posterov $\mathrm{z}$ konferencie usporiadanej pri príležitosti 30 . výročia vyhlásenia Národného parku Nízke Tatry [Nature of Nízke Tatry Mts 2. Proceedings from conference organized on occasion of 30 year anniversary of Nízke Tatry National Park]. Správa Národného parku Nízke Tatry, Banská Bystrica, 260. [In Slovak with abstract in English] SA

[1507] Korňan J \& Šimák L 2009: Orol skalný (Aquila chrysaetos). Správa za rok 2008 [Golden eagle (Aquila chrysaetos). Report from 2008]. Dravce a sovy 5(1): 6. [In Slovak] SA

[1508] Korňan M \& Macek M 2010: Prvé dokumentované pozorovanie rodičovskej infanticídy nasledovanej kanibalizmom u orla skalného (Aquila chrysaëtos) [First documented case of parental infanticide followed by cannibalism in golden eagles (Aquila chrysaëtos)], 10. In: Kropil R \& Lešo P (eds), Aplikovaná ornitológia 2010. Zborník abstraktov z 22. stredoslovenskej ornitologickej konferencie s medzinárodnou účast'ou konanej vo Zvolene 10. septembra 2010 [Applied ornithology 2010. Abstract proceedings from 22nd international ornithological conference in Zvolen, September 10, 2010]. Technická univerzita, Zvolen, 25. [In Slovak] CA 
[1509] Korňan M \& Macek M 2011: Parental infanticide followed by cannibalism in golden eagles (Aquila chrysaetos). Journal of Raptor Research 45(1): 95-96. DOI: 10.3356/JRR-09-77.1. SA

[1510] Korňan J, Macek M, Majda M, Šimák L, Šotnár K, Mihók J, Sedláková B, Pavelka J, Harvančík S, Reistetter R \& Ondruš S 2010: Monitoring a manažment populácie orla skalného na Slovensku za rok 2009 [Monitoring and management of golden eagle population in Slovakia in 2009], 9-10. In: Kropil R \& Lešo P (eds), Aplikovaná ornitológia 2010. Zborník abstraktov z 22. stredoslovenskej ornitologickej konferencie s medzinárodnou účast’ou konanej vo Zvolene 10. septembra 2010 [Applied ornithology 2010. Abstract proceedings from 22nd international ornithological conference in Zvolen, September 10, 2010]. Technická univerzita, Zvolen, 25. [In Slovak] CA

[1511] Krištofík J, Mašán $P$, Šustek Z \& Karaska D 2009: Arthropods in the nests of lesser spotted eagle (Aquila pomarina). Biologia 64(5): 974-980. DOI: 10.2478/s11756-009-0148-x. SA

[1512] Lengyel J 2008: Krúžkovanie mlád'at orliakov morských na Dunaji [Ringing of white-tailed eagles' nestlings at Danube]. Vtáky Leto 2008: 9. [In Slovak] RO

[1513] Literák I, Mrlík V, Hovorková A, Mikulíček P, Lengyel J, Št’astný K, Cepák J \& Dubská L 2007: Origin and genetic structure of white-tailed sea eagles (Haliaeetus albicilla) in the Czech Republic: an analysis of breeding distribution, ringing data and DNA microsatellites. European Journal of Wildlife Research 53: 195-203. DOI: 10.1007/s10344-006-0081-z. SA

[1514] Maderič B 2009: Seminár o ochrane orla krikl'avého [Seminar on lesser spotted eagle protection]. Podvihorlatské noviny 50(52-53): 5. [In Slovak] PA

[1515] Maderič B 2010: Haja červená (Milvus milvus) [Red kite (Milvus milvus)]. Dravce a sovy 6(1): 12. [In Slovak] RO

[1516] Maderič B 2010: Haja tmavá (Milvus migrans) [Black kite (Milvus migrans)]. Dravce a sovy 6(1): 13. [In Slovak] RO

[1517] Maderič B 2010: Názov druhu: Orol krikl’avý (Aquila pomarina) [Species name: lesser spotted eagle (Aquila pomarina)], 6-10. In: RPS (ed), Aktualizácia definovania priaznivého stavu vybraných druhov dravých vtákov [Upda- te of favourable species status of some raptor species]. Ochrana dravcov na Slovensku, Bratislava, 32. [In Slovak] RO

[1518] Maderič B 2012: Haja červená (Milvus milvus) [Red kite (Milvus milvus)]. Dravce a sovy 8(1): 11. [In Slovak] RO

[1519] Maderič B 2012: Haja tmavá (Milvus migrans) [Black kite (Milvus migrans)]. Dravce a sovy 8(1): 12. [In Slovak] RO

[1520] Matejovič B 2009: Úspešná adopcia mlád’at kane močiarnej (Circus aeruginosus) [The successful adoption of the young Marsh Harrier (Circus aeruginosus)]. Dravce a sovy 5(2): 12-13. [In Slovak with English summary] RO

[1521] Meyburg B-U 2001: Zum Kainismus beim Schreiadler Aquila pomarina. Acta Ornithoecologica 4.2-4: 269-278. SA

[1522] Musílek J 1935: Orlové morští na Slovensku [White-tailed eagles in Slovakia]. Stráž myslivosti 13: 653. [In Czech] SA

[1523] Musílek J 1938: Invase motáka jižního (Circus macrourus Gm.). Invasion der Steppenweihe (Circus macrourus Gm.). Sylvia 3: 70. SA

[1524] Nemček V 2009: Kaňa močiarna (Circus aeruginosus) - známa neznáma [The Marsh Harrier (Circus aeruginosus) - known unknown]. Dravce a sovy 5(2): 18-19. [In Slovak with English summary] SA

[1525] Nemček V 2010: Kaňa močiarna (Circus aeruginosus) [Marsh harrier (Circus aeruginosus)]. Dravce a sovy 6(1): 15. [In Slovak] SA

[1526] Noga M 2008: Výzva k spolupráci [Appeal for co-operation]. Dravce a sovy 4(2): 22. [In Slovak with English summary] RO

[1527] Noga M 2010: Kaňa popolavá (Circus pygargus) [Montagu's harrier (Circus pygargus)]. Dravce a sovy 6(1): 14. [In Slovak] RO

[1528] Noga M 2010: Kane za plot! [Harriers behind the fence]. Dravce a sovy 6(2): 10-11. [In Slovak with English summary] PA

[1529] Noga M 2012: Kaňa popolavá (Circus pygargus) [Montagu's harrier (Circus pygargus)]. Dravce a sovy 8(1): 13. [In Slovak] RO

[1530] Obuch J 2012: Potrava mlád'at jastraba krahulca (Accipiter nisus) v horách [Diet of young sparrowhawks (Accipiter nisus) in mountain area]. Dravce a sovy 8(2): 18-19. [In Slovak with English summary] SA

[1531] Očenáš R 2001: S orlami lovia divé líšky [They 
hunt with eagles on wild foxes]. Nový čas 11(7. 11. 2001): 12-13. [In Slovak] PA

[1532] Palášthy J 1960: Z nevedomosti sú škody [Damages from ignorance]. Polovníctvo a rybárstvo 12(9): 8. [In Slovak] PA

[1533] Prešinský L 2010: Šliapanie na vrchol (z denníka dravčiara) [Climbing to the peak (Diary notes)]. Dravce a sovy 6(1): 29-30. [In Slovak with English summary] PA

[1534] Procházka J 2008: Orel mořský. Haliaeetus albicilla. Orliak morský. White-tailed eagle, 279-281. In: Cepák J, Klvaňa P, Škopek J, Schröpfer L, Jelínek M, Hořák $\mathrm{D}$, Formánek $\mathrm{J}$ \& Zárybnický J (eds), Atlas migrace ptáků České a Slovenské republiky. Czech and Slovak bird migration atlas. Aventinum, Praha, 608. [In Czech with English summary] SA

[1535] Purkyně C 1950: Orel skalní (Aquila chrysaetos) v noře svišstě [Golden eagle (Aquila chrysaetos) in marmot burrow]. Sylvia 11-12(3) [1949-50]: 76-77. [In Czech with French summary] SA

[1536] Rác P \& Bohuš M 2011: „Zimné hniezda“ orliakov morských ["Winter nests" of white-taile eagles]. Vtáky 6(1): 5. [In Slovak] RO

[1537] Rác P, Lengyel J, Harvančík S, Chavko J \& Bohuš M 2010: Krúžkovanie mlád'at orliakov morských na Dunaji [Ringing of white-tailed eagles' nestlings at Danube]. Vtáky 5(4): 7. [In Slovak] RO

[1538] Radúch J 2002: Význam predátorov v ekológii tatranského kamzíka [Predator importance in Tatra chamois ecology], 56-66. In: Janiga M \& Švajda J (eds), Ochrana kamzíka [Chamois protection]. Správa Tatranského národného parku, Správa Národného parku Nízke Tatry \& Výskumný ústav vysokohorskej biológie Žilinskej univerzity, Tatranská Štrba, Banská Bystrica \& Tatranská Javorina, 262. [In Slovak with abstract in English] SA

[1539] Rak D 2012: Dva měsíce s pilichy [Two months with hen harriers]. Dravce a sovy 8(2): 4-6. [In Czech with English summary] PA

[1540] RPS (ed) 2010: Aktualizácia definovania priaznivého stavu vybraných druhov dravých vtákov [Update of favourable species status of some raptor species]. Ochrana dravcov na Slovensku, Bratislava, 32. [In Slovak] RO

[1541] Rybanič R 2006: Zranitel'né druhy Európy (3. čast') [Vulnerable species of Europe (part 3.]. Vtáky Leto 2006: 18. [In Slovak] PA
[1542] Schröpfer L 2008: Luňák červený. Milvus milvus. Haja červená. Red kite, 278-279. In: Cepák J, Klvaňa P, Škopek J, Schröpfer L, Jelínek M, Hořák D, Formánek J \& Zárybnický J (eds), Atlas migrace ptáků České a Slovenské republiky. Czech and Slovak bird migration atlas. Aventinum, Praha, 608. [In Czech with English summary] SA

[1543] Schröpfer L, 2008: Luňák hnědý. Milvus migrans. Haja tmavá. Black kite, 277-278. In: Cepák J, Klvaňa P, Škopek J, Schröpfer L, Jelínek M, Hořák D, Formánek J \& Zárybnický J (eds), Atlas migrace ptáků České a Slovenské republiky. Czech and Slovak bird migration atlas. Aventinum, Praha, 608. [In Czech with English summary] SA

[1544] Suchánek O 2011: Hniezdenie orliaka morského (Haliaeetus albicilla) po 50-tich rokoch pri Oravskej priehrade [Nesting of white-tailed eagle (Haliaeetus albicilla) near Orava water dam after 50 years]. Vtáky 6(1): 4-5. [In Slovak] SA

[1545] Šotnár K 1996: Traja králi [Three kings]. Vtáčie správy 3(3): 12. [In Slovak] PA

[1546] Šotnár K 2009: Skončili pod kolesami áut [They died under car wheels]. Dravce a sovy 5(1): 28. [In Slovak with English summary] PA

[1547] Šotnár K 2010: Zaujímavosti z monitoringu jastraba vel'kého (Accipiter gentilis) [Curiosities of the northern goshawk (Accipiter gentilis) monitoring]. Dravce a sovy 6(2): 14-15. [In Slovak with English summary] SA

[1548] Šotnár K \& Beniska R 2004: Orol skalný (Aquila chrysaetos) [Golden eagle (Aquila chrysaetos)]. Spravodaj Lehota pod Vtáčnikom 4: 6. [In Slovak] PA

[1549] Štollmann A 1955: A rétisas újabb fézkelése a csehzlovákiai Duna-Szakaszon. New nesting-sites of the white-tailed eagle near the Danube in Czechoslovakia. Aquila 59-62: 379-380, 437-438. SA

[1550] Väli Ü 2004: The greater spotted eagle Aquila clanga and the lesser spotted eagle Aquila pomarina: taxonomy, phylogeography and ecology. [Dissertationes biologicae Universitatis Tartuensis 86]. Thesis, 32. [Depon. in University of Tartu, Tartu]. QP

[1551] Väli Ü, Dombrovski V, Treinys R, Bergmanis U, Daróczi S, Dravecky $\mathrm{M}$, Ivanovski V, Lontkowski J, Maciorowski G, Meyburg B-U, 
Mizera T, Zeitz R \& Ellegren H 2010: Widespread hybridization between the greater spotted eagle Aquila clanga and the lesser spotted eagle A. pomarina (Aves: Accipitriformes) in Europe. Biological Journal of the Linnean Society 100: 725-736. DOI: $10.1111 /$ j.1095-8312.2010.01455.x. SA

[1552] Väli Ü, Saag P, Dombrovski V, Meyburg B-U, Maciorowski G, Mizera T, Treinys R \& Fagerberg S 2010: Microsatellites and single nucleotide polymorphisms in avian hybrid identification: a comparative case study. Journal of Avian Biology 41: 34-49. DOI: 10.1111/j.1600-048X.2009.04730.x. SA

[1553] Vili N, Horváth $M$, Kovács $S$, Chavko J, Hornung E \& Kalmár L 2009: Alternatív mintavételi módszer gyakorlati alkalmazhatósága madárgenetikai vizsgálatokban: parlagi sasok ivarmeghatározása, mikroszatellitákon alapuló egyedi azonosítása és mtDNS-ének vizsgálata [Alternative sampling methods in avian genetic studies: sexing, microsatellites based individual identification and mtDNA analyses of eastern imperial eagles (Aquila heliaca)]. Magyar Állattorvosok Lapja 131(7): 426-435. [In Hungarian with English abstract] SA

[1554] Vili N, Chavko J, Szabó K, Kovács S, Hornung E, Kalmár L \& Horváth M 2009: Genetic structure of the imperial eagle (Aquila heliaca) population in Slovakia. Slovak Raptor Journal 3: 21-28. DOI: 10.2478/v10262-012-0029-z. SA

$\mathrm{F}$ a $1 \mathrm{c}$ o n i f o r m e s

[1555] Bagyura J, Fidlóczky J \& Prommer M 2010: Conservation of the saker falcon in the Carpathian Basin 2006-2010. Halmos Gergő, MME/BirdLife Hungary, Budapešt', 20. RO

[1556] Bagyura J, Fidlóczky J \& Prommer M 2010: A Kerecsensólyom védelme a Kárpát-medencében 2006-2010 [Conservation of the saker falcon in the Carpathian Basin 2006-2010]. Halmos Gergő, MME/BirdLife Hungary, Budapest, 20. [In Hungarian] RO

[1557] Chavko J 2010: Názov druhu: Sokol rároh (Falco cherrug) [Species name: saker falcon (Falco cherrug)], 15-18. In: RPS (ed), Aktualizácia definovania priaznivého stavu vybraných druhov dravých vtákov [Update of favourable species status of some raptor species]. Ochrana dravcov na Slovensku, Bratislava, 32. [In Slovak] RO
[1558] Chavko J 2012: Sokol kobcovitý (Falco vespertinus) [Red-footed falcon (Falco vespertinus)]. Dravce a sovy 8(1): 10. [In Slovak] RO

[1559] Chavko J 2012: Sokol rároh (Falco cherrug) [Saker falcon (Falco cherrug)]. Dravce a sovy 8(1): 8. [In Slovak] RO

[1560] Chavko J 2012: Sokol st’ahovavý (Falco peregrinus) [Peregrine falcon (Falco peregrinus)]. Dravce a sovy 8(1): 9. [In Slovak] RO

[1561] Chavko J \& Maderič B 2010: Názov druhu: Sokol st'ahovavý (Falco peregrinus) [Species name: peregrine falcon (Falco peregrinus)], 19-22. In: RPS (ed), Aktualizácia definovania priaznivého stavu vybraných druhov dravých vtákov [Update of favourable species status of some raptor species]. Ochrana dravcov na Slovensku, Bratislava, 32. [In Slovak] RO

[1562] Deutschová L 2009: Massacre en Slovaquie. Les notes du pèlerin 13\&14: 14-16. RO

[1563] Imrich P \& Krišovský P 2011: Zachránený sokolík [Small falcon saved]. Vtáky 6(3): 9. [In Slovak] PA

[1564] Janda J 1932: Raroh veliký evropský (Falco cherrug cherrug Gray) na Slovensku [Saker falcon (Falco cherrug cherrug Gray) in Slovakia]. Věda prírodní 13: 107-109. [In Czech] SA

[1565] Jeitteles LH 1861: Ueber zwei für die Fauna Ungarns neue Vögel: Falco cenchris Naum. und Larus argentatus Brünnich. Verhandlungen der keisertlich-königlichen zoologisch-botanischen Gesellschaft in Wien 11: 327-329. SA

[1566] Kunszt K 1929: A kerecsen sólyom, vagy ráró (Falco lanarius) mint fészkelo madár a Csallóközben [Saker falcon (Falco lanarius) is breeding in Žitný ostrov]. Kárpáti vadász 3: 19-20. [In Hungarian] SA

[1567] Musílek J 1931: Raroh velký u Trnavy [Saker falcon near Trnava]. Stráž myslivosti 9: 127. [In Czech] SA

[1568] Musílek J 1933: Ještě o rarohu velkém [More on saker falcon]. Stráž myslivosti 11: 87-88. [In Czech] SA

[1569] Nagy J 1908: Vándorsólymok a Simonkai Hegységben [Peregrine falcons in Šimonka Mt]. Állatvilág 1908: 91-97. [In Hungarian] SA

[1570] Pačenovský S 1996: Vplyv pesticídov na divú zver a vtáctvo [Pesticide impact on wildlife and birds]. Vtáčie správy 3(1): 10. [In Slovak] RO

[1571] Sitko J 1992: Parazitičtí červi a jejich vliv na zdravotní stav dravců (Falconiformes) a sov 
(Strigiformes) [Parasitic worms (the helmints) and their influence on the health condition of birds of prey (Falconiformes) and owls (Strigiformes)]. Zprávy MOS 50: 53-56. [In Czech with English summary] SA

[1572] Uličná L 2008: Sokolovité vtáky (Falconidae) na Slovensku [Falcons (Falconidae) in Slovakia]. Bachelor thesis, 46. [Depon. in Institute of biology and ecology, Faculty of scince, PJ Šafárik University, Košice]. [In Slovak] QP

$\mathrm{Strig}$ i f or m e s

[1573] Dobrý M 2011: The abundance of the little owl (Athene noctua) in Podunajská rovina lowland in 2009 and 2010. Slovak Raptor Journal 5: 121-126. DOI: $10.2478 / \mathrm{v} 10262-012-0058-7$. SA

[1574] Dobrý M \& Chrenková M 2012: Kuvik obyčajný (Athene noctua) [Little owl (Athene noctua)]. Dravce a sovy 8(1): 14-15. [In Slovak] SA

[1575] Formánek J \& Škopek J 1988: Přehled kroužkování sov v ČSSR a jeho výsledky v letech 1934-85 [Outline of owls' ringing in Czechoslovakia and its results in 1934-85], 55-65. In: Sitko J \& Trpák P (eds), Sovy 1986, Sborník z ornitologické konference Přerov 14. a 15. 11. 1986 [Owls 1986, Proceedings from ornithological conference Přerov, November 14 and 15, 1986]. Státní ústav památkové péče a ochrany př́rody $\mathrm{v}$ Praze ve spolupráci s Okresním vlastivědným muzeem J. A. Komenského a Moravským ornitologickým sdružením v Přerově ve Státním zemědělském nakladatelství v Praze, Praha, 164. [In Czech with German summary] RO

[1576] Herz J 1989: Nezabúdajme na sovy [Do not forget on owls]. Pol'ovníctvo a rybárstvo 41(2): 58. [In Slovak] PA

[1577] Kocyan A 1891: Der Rauhfusskauz (Nyctala tengmalmi $(\mathrm{Gm})$.$) in der Tatra. Zeitschrift für$ die gesammte Ornithologie 2: 250-251. SA

[1578] Krištín A 1987: Überlappung trophischer Ansprüche der Nestlinge Asio otus und Falco tinnunculus in den Windbrechern der Schüttinsel. Biológia 42(6): 625-635. SA

[1579] Noga M 2012: Nová pracovná skupina? Kýho výra! [New working group found?]. Dravce a sovy 8(1): 26. [In Slovak with English summary] RO

[1580] Noga M 2012: Zimné sčítanie myšiarok ušatých (Asio otus) na juhozápadnom Slovensku 2011/2012 [Winter census of long-eared owls
(Asio otus) in south-western Slovakia 2011/2012]. Dravce a sovy 8(1): 18. [In Slovak] SA

[1581] Obuch J 2004: Zastúpenie ryšaviek (rod Apodemus) $\mathrm{v}$ potrave sov (Strigiformes) na Slovensku [The representation of field mice (genus Apodemus) in the diet of owls (Strigiformes) in Slovakia], 67-80. In: Adamec M \& Urban P (eds), Výskum a ochrana cicavcov na Slovensku VI. Zborník referátov z konferencie (10.-11. 10. 2003) [Research and protection of mammals in Slovakia VI. Conference proceedings (October 10-11, 2003)]. Štátna ochrana prírody SR, Centrum ochrany prírody a krajiny, Banská Bystrica, 192. [In Slovak with English abstract] SA

[1582] Obuch J 2005: Význam štúdia potravnej ekológie sovy obyčajnej (Strix aluco) pre poznanie diverzity lesných ekosystémov [Importance of tawny owl (Strix aluco) diet study for forest ecosystems understanding]. Dissertation thesis project, 27. [Depon. in Department of forest protection and game management, Faculty of forestry, Technical University, Zvolen]. [In Slovak] QP

[1583] Obuch J 2011: Spatial and temporal diversity of the diet of the tawny owl (Strix aluco). Slovak Raptor Journal 5: 1-120. DOI: 10.2478/v10262-012-0057-8. SA

[1584] Obuch J \& Khaleghizadeh A 2011: Spatial variation in the diet of the barn owl Tyto alba in Iran. Podoces 6(2): 103-116. SA

[1585] Pačenovský S \& Chrašč P 2011: Hniezdenie výrika lesného (Otus scops) v CHVÚ Senianske rybníky [Breeding of the scops owl (Otus scops) in „Senianske rybníky“ SPA]. Dravce a sovy 7(2): 10-11. [In Slovak with English summary] SA

[1586] Pačenovský S \& Šotnár K 2012: Kuvičok vrabčí (Glaucidium passerinum) [Pygmy owl (Glaucidium passerinum)]. Dravce a sovy 8(1): 16. [In Slovak] RO

[1587] Poláček M 2009: Analýza potravy sovy lesnej (Strix aluco, Strigiformes) v mestských a prirodzených podmienkach [Tawny owl (Strix aluco, Strigiformes) diet analysis in urbanized and natural conditions]. Thesis, 59. [Depon. in Department of zoology, Faculty of natural sciences, Comenius University, Bratislava]. [In Slovak with English abstract] QP

[1588] Poláček M, Baláž M \& Obuch J 2012: Potrava sovy obyčajnej (Strix aluco) v urbánnom a lesnom prostredí [Diet of the Tawny Owl (Strix 
aluco) in urban and forest environment]. Tichodroma 24: 29-39. [In Slovak with English abstract] SA

[1589] Považan R 2003: Naše prvé sovníky [Our first nest boxes for owls]. Vtáčie správy 10(1): 20. [In Slovak] PA

[1590] Račková R 2009: Spoločenstvá drobných zemných cicavcov $\mathrm{v}$ potrave sov Ipel'skej kotliny [Small mammlas communities in diet of owls in Ipel'ská kotlina Basin]. Thesis, $70+$ appendices. [Depon. in Department of zoology, Faculty of natural sciences, Comenius University, Bratislava]. [In Slovak with English abstract] QP

[1591] Randík A 1986: Výskum potravy sov [Research of owls' diet], 141. In: Anonymus (eds), Možnosti SZOPK pri ochrane fauny SSR. Metodicko-námetová príručka č. 6 [Opportunities of SZOPK in fanuna protection in Slovakia. Methodological guide no. 6]. ÚV SZOPK, Bratislava, 201. [In Slovak] RO

[1592] Roulin A \& Dubey S 2012: The occurrence of reptiles in barn owl diet in Europe. Bird Study 59: 504-508. DOI: 10.1080/00063657.2012.731035. SA

[1593] Sabadoš K \& Sládek J 1968: Príspevok k poznaniu potravy dravcov a sov v bažantnici počas mimoriadne krutej zimy [On diet of raptors and owls in pheasantery in extraordinary cruel winter]. Biológia 23(5): 363-369. [In Slovak with Russian and German summaries] SA

[1594] Sárossy M 2004: Soví kurz [Course on owls]. Vtáčie správy 11(4): 16. [In Slovak] PA

[1595] Šipkovský I 2012: Ako u nás kuviky vyhniezdili, alebo príbeh posledného známeho hniezdenia kuvika obyčajného $v$ dutine stromu na Slovensku [How the little owls successfully nested by us or the last known breeding of little owl in the tree hollow in Slovakia]. Dravce a sovy $8(2)$ : 10-11. [In Slovak with English summary] SA

[1596] Šotnár K 2012: Výrik obyčajný (Otus scops) [Scops owl (Otus scops)]. Dravce a sovy 8(1): 17. [In Slovak] SA

[1597] Šotnár K \& Pačenovský S 2011: Mapovanie sov (Strigiformes) v pohorí Vel'ká Fatra v rokoch 2010-2011 [Owl surwey (Strigiformes) in the „Vel'ká Fatra“" Mts in 2010-2011]. Dravce a sovy 7(2): 12-13. [In Slovak with English summary] SA

[1598] Šotnár K, Tulis F \& Obuch J 2012: Dlhodobé sledovanie potravy zimujúcich myšiarok ušatých (Asio otus, L. 1758.) v Bojniciach (stredné Slovensko) [Long-term investigation of diet of wintering long-eared owls (Asio otus, L. 1758.) in Bojnice (central Slovakia)], 191-192. In: Bryja J, Albrechtová J \& Tkadlec E (eds), Zoologické dny Olomouc 2012. Sborník abstraktů z konference 9.-10. února 2012 [Zoological days Olomouc 2012. Abstract proceedings from conference, February 9-10, 2012]. Ústav biologie obratlovců AV ČR, Brno, 242. [In Slovak] CA

[1599] Tulis F, Slobodník R, Kaplan D \& Šotnár K 2011: Telemetria myšiarok ušatých na Hornej Nitre [Telemetry of the long-eared owls in „Horná Nitra" region]. Dravce a sovy 7(2): 14-16. [In Slovak with English summary] SA

[1600] Tulis F, Šotnár K \& Obuch J 2012: Dlhodobé sledovanie zmien potravy zimujúcich myšiarok ušatých (Asio otus) [Long-term investigation of changes in diet of wintering long-eared owls (Asio otus)], 177-178. In: Kubovčík V \& Stašiov S (eds), Zborník príspevkov z vedeckého kongresu "Zoológia 2012", 18. Feriancove dni [Proceedings from congress "Zoology 2012", 18th Ferianc days]. Technická univerzita vo Zvolene, Zvolen, 188. [In Slovak with abstract in English] CA 


\section{Species index}

Accipiter gentilis - 1217, 1337, 1342, 1492, 1547

Accipiter nisus - 1459, 1465, 1530

Aegolius funereus - 1577

Aquila chrysaetos - 1361, 1424,

1463-1468, 1474, 1483, 1496,

$1497,1507-1510,1532,1533$,

$1535,1538,1545,1548$

Aquila clanga - 1361, 1550, 1551

Aquila heliaca - 1213, 1281, 1342, $1476,1478,1480,1481,1485$, 1486, 1491, 1495, 1553, 1554

Aquila pomarina - 1337, 1424, $1458,1459,1482,1487-1490$, 1493, 1501-1506, 1511, 1514, 1517, 1521, 1550-1552

Asio flammeus - 1526

Asio otus - 1337, 1526, 1578, 1580, 1598, 1599, 1600

Athene noctua - 1573, 1574, 1595

Bubo bubo - 1256, 1579

Buteo buteo - 1337, 1338, 1459,

1465, 1466, 1546

Circaetus gallicus - 1213, 1484

Circus aeruginosus - 1256, 1337,

1338, 1520, 1524, 1525

Circus cyaneus - 1424, 1499, 1526, 1539

Circus macrourus - 1424, 1523

Circus pygargus - 1337 ,

1527-1529

Falco - 1570, 1572

Falco cherrug - 1210, 1213, 1215, 1555-1557, 1559, 1562, 1564, 1566-1568

Falco columbarius - 1424

Falco naumanni - 1565

Falco peregrinus - 1213, 1215, 1424, 1494, 1560, 1561, 1569

Falco subbuteo - 1215, 1337, 1338

Falco tinnunculus - 1331, 1337,

1338, 1459, 1563, 1578

Falco vespertinus - 1213, 1424, 1558

Glaucidium passerinum - 1215, 1586

Haliaeetus albicilla - 1215, 1406, 1424, 1469-1473, 1475, 1477, $1479,1498,1500,1512,1513$,
$1522,1534,1536,1537,1544,1549$

Hieraaetus pennatus - 1213, 1361, 1424

Milvus migrans - 1424, 1516, 1519, 1543

Milvus milvus - 1515, 1518, 1542

Otus scops - 1406, 1585, 1596

Pandion haliaetus - 1424

Pernis apivorus - 1215

Strix aluco - 1582, 1583, 1587, 1588

Tyto alba - 1337, 1584, 1592

\section{Other species}

Acari - 1220

Anas clypeata - 1361

Apodemus - 1581

Ceratophyllus - 1241

Corvus corax - 1361

Dasypsyllus - 1241

Larus argentatus -1565

Lepus europaeus - 1338

Marmota marmota - 1463, 1464, 1535

Mesostigmata - 1220

Microtus arvalis - 1338

Ornithophaga-1241

Phylloscopus collybita - 1331

Rupicapra rupicapra - 1538

Siphonaptera - 1241, 1242

Spermophilus citellus - 1342

Trypanosoma avium - 1459

Trypanosoma corvi- 1458

\section{Objective index}

Abundance - 1271, 1323, 1326, 1333, 1348, 1363, 1364, 1366, $1403,1417,1454,1455,1456$, $1457,1506,1573$

Acoustic monitoring - 1336

Bird crime - 1225, 1226, 1234, $1278,1285,1322,1330,1341$, $1349,1350,1372,1388,1412$, $1449,1462,1502,1562$

Bird records - 1213, 1465

Cainism - 1521

Captive breeding - 1294, 1295

Census - 1367, 1470, 1472, 1473, 1580

Conferences - 1281, 1303, 1321,
$1418,1439,1469,1514$

Conservation - 1221, 1228, 1231, 1232, 1276, 1300-1302, 1304-1306, 1314, 1320, 1327, $1347,1378,1391,1402$, 1410-1415, 1420-1423, 1434, 1450, 1461, 1485, 1493, 1501, $1532,1541,1555,1556$

Distribution / occurrence - 1244, $1245,1256,1270,1271,1307$, 1308, 1312, 1326, 1333, 1340, 1343, 1346, 1361, 1398, 1399, $1400,1406,1424,1443,1444$, 1452-1457, 1495, 1513, 1597 Diet - 1313, 1315, 1331-1334, 1370, 1416, 1424, 1474, 1530, 1578, 1581-1584, 1587, 1588, 1590, 1591-1593, 1598, 1600 Editorials \& prefaces - 1212, 1214, 1280, 1282, 1368, 1369, 1371, $1374,1375,1377,1382,1383$, 1386, 1404, 1405

Electrocution - 1204, 1238, 1240 , $1279,1283,1311,1358,1384$, 1397,1486

Ethology - 1508

Falconry - 1217, 1219, 1223, 1292, 1293, 1319, 1322, 1350, 1352, $1353,1357,1365,1407,1433,1531$ Favourable species status -1517 , 1540, 1557, 1561

General information - 1208, 1224, $1227,1312,1318,1345,1387$, $1401,1419,1435$

History - 1316, 1420-1422

Hunting - 1316, 1322

Hybridization - 1551

Infanticide - 1508, 1509

Interspecies interactions - 1338 , 1442, 1578

Microsatellites - 1468, 1498, 1513, 1552-1554

Migration - 1481-1483, 1534, 1542,1543

Mitochondrial DNA - 1498

Monitoring - 1237, 1239, 1255, 1360, 1501, 1510

Museum collections - 1222, 1324

Nesting / breeding - 1317, 1362, 1440, 1441 
Nest guarding - 1349, 1351, 1451

Nest fauna -1511

Organization - 1198, 1199, 1200, 1205-1207, 1209, 1216, 1233, $1235,1246-1255,1257-1262$, 1264-1268, 1272-1275, 1284, 1286, 1309, 1344, 1373, 1376, $1379,1381,1385,1445,1446$, 1460, 1526, 1579, 1589, 1594

Parasitology - 1220, 1241, 1242, 1432, 1458, 1459, 1571

Pesticides - 1243, 1570

Personalia - 1218, 1236, 1269, 1328, 1355

Phylogeography -1550

Protected areas $-1221,1231,1244$, 1245, 1300, 1301, 1304, 1337, 1346, 1389, 1390, 1392, 1393-1396, 1400, 1443, 1495, 1506, 1585

Public awareness - 1210, 1277, 1325, 1409

Rescue - 1201-1203, 1335, 1344, 1356, 1359, 1431, 1486, 1520, 1563

Review / publications - 1211, 1287-1291, 1408, 1425, 1447, 1448 Ringing / marking / banding - 1229, 1230, 1263, 1298, 1299, 1310, 1380, 1426-1430, 1436, 1437, 1490, 1494, 1503, 1504, 1512, $1513,1537,1575$

Satellite tracking - 1354, 1438

Taxonomy -1550

Traffic casualties -1546

Trends - 1228

Vernacular names - 1296, 1297 , 1329

Wintering - 1470, 1472, 1580, 1600

\section{Author index}

Adamec M - 1198-1204

Anonymus - 1205-1210,

1212-1216

Babó T - 1217-1219

Bačíková S - 1220

Bagyura J - 1555, 1556

Balaška V -1452

Baláž M - 1588

Ballo P - 1463, 1464

Barčák C - 1221
Baum J - 1465

Beneš $\mathrm{B}-1222$

Beniska B - 1466

Beniska R - 1548

Benko Š - 1223

Bergmanis U - 1490, 1551

Bernavent-Corai J - 1343

Bethlenfalvy E - 1224, 1467

Bielikova M - 1468

Bohuš M - 1469-1473, 1536, 1537

Brinzík M - 1225, 1226

Brtek V - 1227

Burfield I - 1228

Cepák J - 1229, 1230, 1513

Chavko J - 1221, 1231-1240,

1271-1275, 1285, 1387, 1393,

1475-1480, 1485, 1537, 1553,

1554, 1557-1561

Chrašč P -1585

Chrenková M - 1574

Cyprich D - 1241, 1242

Čalkovský M - 1474

Čihák K - 1243

Danko Š - 1244-1275, 1363, 1364,

1366, 1481-1485

Daróczi S - 1551

Darolová A - 1270, 1276, 1366

Demeter G - 1485, 1495

Deutschová L - 1277-1285, 1387,

1486, 1562

Devečka V - 1505

Diviš T - 1271, 1286

Divok F - 1301

Dobrý M - 1573, 1574

Dombrovski V - 1490, 1551, 1552

Dravecký M - 1287-1290, 1430,

1487-1490, 1493, 1551

Dražil T - 1301

Dubey S - 1592

Dubravský A - 1291, 1491, 1495

Dubská L - 1498, 1513

Dvorská J - 1271

Dvorský M - 1271

Eck S - 1492

Ellegren $\mathrm{H}-1551$

Fagerberg S - 1552

Fekete L - 1292-1295

Fend'a P -1220

Ferianc O - 1296, 1297

Ficek A - 1468
Fidlóczky J - 1555, 1556

Formánek J - 1298, 1299, 1436, 1437,1575

García-Ripollés C - 1343

Gúgh J - 1339

Guziová Z - 1493

Hailer F - 1498

Hájek B - 1300-1302

Hanák F - 1222

Hapl E - 1303, 1304

Haršáni L - 1305, 1306

Harvančík S - 1307-1312, 1494,

1495, 1510, 1537

Hatinová M - 1496

Hell P - 1313, 1423

Herz J - 1576

Hetzendorf E - 1497

Hol'ma J - 1314

Honnen A-C - 1498

Hornung E - 1553, 1554

Horváth $\mathrm{M}-1553,1554$

Hovorková A - 1513

Hrabár S - 1315

Hudeček J - 1222

Imrich P - 1563

Ivanovski V - 1551

Izakovič A - 1499

Izakovič J - 1485

Jamnický J - 1316

Janda J - 1564

Jeitteles LH - 1565

Jenei R - 1317

Jirsík J - 1318

Kalmár L - 1553, 1554

Kampf V - 1319

Kaňuch P - 1211

Kaňuščák P - 1500

Kaplan D - 1599

Karaska D - 1242, 1271-1273,

1275, 1320, 1321, 1511

Kaššák A - 1306, 1322

Kenntner N-1498

Khaleghizadeh A - 1584

Kicko J - 1323-1326, 1501-1506

Kloubec B - 1271

Klvaňa P - 1229, 1230

Kocyan A - 1577

Kormančík J - 1302

Korňan J - 1327, 1328, 1507-1510

Korňan M - 1474 
Kovács $\mathrm{S}-1553,1554$

Kovalik P - 1329

Krajčovič I - 1330

Krišovský P -1563

Krištín A - 1270, 1331, 1332, 1366, 1578

Krištofík J - 1511

Kropil R - 1333, 1334, 1366, 1398, 1399

Krumpál M - 1241, 1242

Kukučka M - 1339

Kukurugya $\mathrm{S}-1335$

Kunszt K - 1566

Kurka P - 1271

Kürthy A - 1336

Latková $\mathrm{H}-1485$

Lengyel J - 1337-1339, 1393,

$1471,1472,1512,1513,1537$

Leskovjanská A - 1301

Lešinský $\mathrm{G}-1340$

Lispuchová $\mathrm{S}-1341$

Literák I - 1498, 1513

Löbbová D - 1342

Lontkowski J - 1490, 1551

López-López P - 1343

Lukeš J - 1458, 1459

Macek M - 1328, 1344, 1474,

1508-1510

Maciorowski G - 1490, 1551, 1552

Madarász J - 1345

Maderič B - 1346-1348, 1387,

1392-1396, 1490, 1493,

1514-1519, 1561

Majda M - 1349, 1510

Majko P - 1350, 1462

Májsky J - 1351

Maroši I - 1352

Martinka J - 1353

Mašán $P$ - 1511

Matejovič B - 1520

Matušík H - 1271

Meyburg B-U - 1354, 1355, 1490,

$1521,1551,1552$

Meyburg C - 1354

Mihók J - 1485, 1510

Michal P - 1356, 1357

Mikiara $\breve{S}-1348$

Mikulíček P - 1513

Minka MS - 1358

Mizera T - 1490, 1551, 1552
Mlynek V - 1359

Moncman D - 1360

Mošanský A - 1361, 1362, 1424

Mrlík V - 1363, 1364, 1513

Mucha F - 1365

Murin B - 1366

Musílek J - 1522, 1523, 1567, 1568

Nagy J - 1569

Nemček V - 1367, 1485, 1524, 1525

Newton I - 1355

Noga M - 1368-1388, 1394-1396,

1485, 1526-1529, 1579, 1580

Nuhličková S - 1389-1396

Oborník M - 1458, 1459

Obuch J-1530, 1581-1584, 1588,

1598,1600

Očenáš R - 1531

Ondrišová J - 1397

Ondruš S - 1510

Ostrihoň M - 1398, 1399

Pačenovský S - 1329, 1570, 1585,

1586, 1597

Palášthy J -1532

Pavelčík P - 1339

Pavelka J - 1510

Pčola S -1400

Pecina P - 1401

Pečenák V - 1348

Peške L - 1271

Plachý J - 1241

Poláček M - 1587, 1588

Považan R - 1589

Prešinský L - 1533

Procházka J - 1534

Prokop P - 1442

Prommer M - 1555, 1556

Purkyně C - 1535

Rác P - 1471, 1472, 1536, 1537

Račková R - 1590

Radúch J - 1538

Rak D - 1539

Randík A - 1292, 1293, 1402-1406,

1591

Reistetter R - 1510

Ridzoň J - 1473

Roulin A - 1592

RPS - 1540

Rybanič R - 1541

Saag P - 1552
Sabadoš K - 1593

Sándor AK

Sárossy M - 1594

Sedláková B - 1510

Sellis U -1490

Schön JT - 1407

Schröpfer L-1271, 1408, 1542, 1543

Siklienka R - 1495

Siryová S - 1242, 1274, 1485

Sitko J - 1571

Skalová M - 1409

Sládek J - 1334, 1410-1424, 1593

Slobodník R - 1428-1430, 1599

Slobodník V - 1425-1430

Stanková E - 1431

Stój M - 1490

Suchánek O - 1544

Svobodová M - 1432, 1459

Sýkora J - 1463, 1464

Szabó K - 1554

Šášky M - 1433

Šimák L - 1434, 1440, 1441, 1507, 1510

Šimončič A - 1435

Šipkovský I - 1595

Škopek J - 1298, 1299, 1436, 1437, 1575

Šmelková V - 1438

Šnírer L - 1495

Šotnár K - 1466, 1510, 1545-1548,

1586, 1596-1600

Št’astný K - 1439, 1513

Štollmann A - 1549

Šustek Z - 1511

Švehlík J - 1434, 1440, 1441

Topercer J - 1329

Treinys R - 1490, 1551, 1552

Trnka A - 1442

Tulis F - 1598-1600

Turis $\mathrm{P}-1443$

Turna J - 1468

Tužinský J - 1444

Uhrín J - 1226

Uhrin M - 1211, 1387, 1445-1448

Uhrinová D - 1449

Uličná $\mathrm{L}-1572$

Urban F - 1450

Vacík R - 1271

Váczi M - 1472 
Valkova D - 1468

Varga J - 1451

Väli Ü - 1550-1552

Vd'ačný A - 1388

Veselovský T - 1342

Vician V-1452
Vili N - 1553, 1554

Vít’az V - 1294, 1295

Vlachovičová M - 1453

Volf P - 1459

Voskár J - 1454-1457

Votýpka J - 1458, 1459
Vrlík P - 1506

Wójciak J - 1490

Zachos FE - 1498

Zeitz R - 1551

Zuskin J - 1460

Zuskinová M - 1461, 1462

\section{Appendix: names and places of issue of journals used in bibliography}

Acta Oecologica - Paris

Acta Ornithoecologica - Jena

Acta Protozoologica - Kraków

Acta Zoologica Bulgarica - Sofia

Állatvilág - Budapest

Ambio - Dordrecht

Aquila - Budapest

Ardea - Zeist

Biologia, Biológia - Bratislava

Biological Journal of the Linnean Society - Hoboken

Bird Study - Oxon

Bulletin Réserves Naturelles et Ornitologiques de Belgique - Brussels

Buteo - Pardubice, Česká Skalice, Třeboň, Př́bram

Castrum Novum - Nové Zámky

Československá ochrana prírody - Bratislava

Československá ochrana prírody, Výskumné práce

z ochrany prírody - Bratislava

Denisia - Linz

Chránené územia Slovenska - Bratislava \& Banská

Bystrica

Dravce a sovy - Bratislava

Enviromagazín - Banská Bystrica

European Journal of Wildlife Research - New York

Folia venatoria [Pol'ovnícky zborník] - Zvolen

Informačný bulletin, SAŽP Banská Bystrica - Banská

Bystrica

Journal of Avian Biology - Hoboken

Journal of Raptor Research - Hastings

Kárpáti vadász - Berehovo

Kroužkovatel - Praha

Kultúra slova - Bratislava

Les - Bratislava

Les notes du pèlerin - Paris

Magyar Állattorvosok Lapja - Budapest

Moment - Bratislava

Moravský ornitolog - Přerov

Národná obroda - Bratislava
Národné parky - Liptovský Mikuláś

Naše pol’ovníctvo - Bratislava

Naturae Tutela - Liptovský Mikuláš

Nový čas - Bratislava

Nový deň - Bratislava

Ochrana fauny - Bratislava

Ochrana prírody - Bratislava

Ochrana prírody Slovenska - Banská Bystrica

Ochrana př́rody - Praha

Ornithologisches Jahrbuch - Hallein

Památky a príroda - Praha

Pamiatky - Príroda - Bratislava

Parasitology - New York

Pod Pol'anou, zpravodaj SZOPK - Zvolen

Podoces - Teheran

Podvihorlatské noviny - Humenné

Pol’ovnícky zborník - see Folia venatoria

Polovníctvo a rybárstvo - Bratislava

Poznaj a chráň - Bratislava

Reussia - Revúca

Rol'nícke noviny - Bratislava

Rosalia - Nitra

Sinter - Liptovský Mikuláš

Skupina pro výzkum dravých ptáků a sov, Zprávy

Slovak Raptor Journal - Bratislava

Slovenka - Bratislava

Slovenské pohl'ady - Bratislava

Sme plus - Bratislava

Spravodaj Lehota pod Vtáčnikom - Lehota pod

Vtáčnikom

Spravodaj Slovenskej speleologickej spoločnosti -

Liptovský Mikuláš

Správy Slovenskej zoologickej spoločnosti SAV -

Bratislava

Stráž myslivosti - Praha

Sylvia - Praha

Tatry - Tatranská Lomnica

Telekia - Michalovce 
Természettudományi közlöny - Budapest

Tichodroma - Bratislava, Zvolen

Tracker News - Columbia

Věda prírodní - Praha

Verhandlungen der keisertlich-königlichen zoologischbotanischen Gesellschaft in Wien - Wien

Vtáčie správy - Bratislava

Vtáky - Bratislava
Zeitschrift für die gesammte Ornithologie - Budapest Zoologické listy - Brno

Zoologische Abhandlungen aus dem Staatliches Museum für Tierkunde in Dresden - Dresden Zprávy Československé ornitologické společnosti Zprávy MOS - Přerov

Život - Bratislava 